\title{
Systems Assessment of Atmospheric Fluidized-Bed Combustion: Baseline Study
}
J. E. Jones, Jr.
L. E. McNeese
G. Samuels
M. Siman-Tov
H. D. Cochran
T. G. Godfrey
R. E. Kuhlmann 


\section{DISCLAIMER}

This report was prepared as an account of work sponsored by an agency of the United States Government. Neither the United States Government nor any agency Thereof, nor any of their employees, makes any warranty, express or implied, or assumes any legal liability or responsibility for the accuracy, completeness, or usefulness of any information, apparatus, product, or process disclosed, or represents that its use would not infringe privately owned rights. Reference herein to any specific commercial product, process, or service by trade name, trademark, manufacturer, or otherwise does not necessarily constitute or imply its endorsement, recommendation, or favoring by the United States Government or any agency thereof. The views and opinions of authors expressed herein do not necessarily state or reflect those of the United States Government or any agency thereof. 


\section{DISCLAIMER}

Portions of this document may be illegible in electronic image products. Images are produced from the best available original document. 


\section{Printed in the United States of America. Available from}

National Technical Information Service

U.S. Department of Commerce 5285 Port Royal Road, Springfield, Virginia 22161

Price: Printed Copy $\$ 5.25$; Microfiche $\$ 3.00$

This report was prepared as an account of work sponsored by an agency of the United States Government. Neither the United States Government nor any agency thereof, nor any of their employees, contractors, subcontractors, or their employees, makes any warranty, express or implied, nor assumes any legal liability or responsibility for any third party's use or the results of such use of any information, apparatus, product or process disclosed in this report, nor represents that its use by such third party would not-infringe privately owned rights. 
Contract No. W-7405-eng-26

\section{SYSTEMS ASSESSMENT OF ATMOSPHERIC \\ FLUIDIZED-BED COMBUSTION: \\ BASELINE STUDY}
J. E. Jones, Jr.
L. E. McNeese
G. Samuels
M. Siman-Tov
H. D. Cochran
T. G. Godfrey
R. E. Kuhlmann

Date Published - May, 1978

This report was prepared es an account of work puisured by the United States Covemment. Neither the United States nor the United States Department of Energy, nor any of their employees, nor any of their mnniractnrs, subcontractors. or their employees, makes sny warranty, express or implied, or assumes any legal liability or responsibility for the accuracy, completeness or usefulness of any information, apparatus, product ox process disclosed, or represents that its use would not infringe privately owned rights.

OAK RIDGE NATIONAL LABORATORY

Oak Ridge, Tennessee 37830 operated by UNION CARBIDE CORPORATION

for the DEPARTMENT OF ENERGY 
THIS PAGE

\section{WAS INTENTIONALLY LEFT BLANK}




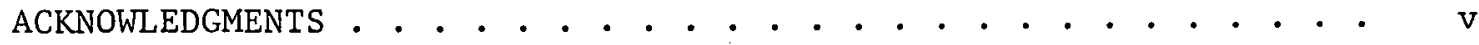

ABSTRACT . . . . . . . . . . . . . . . . . . . . vii

INIRODUCTION . . . . . . . . . . . . . . . . . . . . 1

MAJOR ISSUES AND QUESTIONS . . . . . . . . . . . . . . . 3

Market Potential. . . . . . . . . . . . . . 3

Comparative Econumics . . . . . . . . . . . . . 4

Technical Issues................... . 6

Solids handling systems... . . . . . . . . . 6

Fuel feed system................ . 6

Ash and spent-sorbent handling system . . . . . 8

System control and instrumentation . . . . . . . . . 8

System control................ 8

Instrumentation ............. . 10

Boiler thermal efficiency. . . . . . . . . . . . 10

Chemical reactions... . . . . . . . . . . . 11

Sensible heat losses... . . . . . . . . . 11

Carbon losses ................. 11

Overall system efficiency... . . . . . . . . . . 12

Materials . . . . . . . . . . . . . . . . 13

In-bed heat exchanger tubes . . . . . . . . 13

Air distribution plate... . . . . . . . . 14

Side walls................ . 14

Coal feed lines and nozzles . . . . . . . . 14

Spent-bed removal, hardware........... 14

Cyclones... . . . . . . . . . . . . 15

Materials summary .............. 15

Data base and predictive models... . . . . . . 15

Environmental Control . . . . . . . . . . . . . . 16

$\mathrm{SO}_{2}$ emissions... . . . . . . . . . . . . . . . . 16

$\mathrm{NO}_{\mathrm{X}}$ emissions . . . . . . . . . . . . . . . . . . 17

Falliculate emissions. . . . . . . . . . . . . . . 17

Solids disposal. . . . . . . . . . . . . 18

WORK STATEMENT FOR EXECUTION PHASE OF AFBC SYSTEMS

ANALYSIS AND TECHNOLOGY ASSESSMENT . . . . . . . . . . . . . . . 19

Objective . . . . . . . . . . . . . . . . . . . . . . . 19

Background and Justification . . . . . . . . . . . . 19

Proposed Approach . . . . . . . . . . . . . . . . . . 20

Arteds of Invest1gation and Emphasis . . . . . . . . . . 21

Market potential . . . . . . . . . . . . . 21

Comparative economics... . . . . . . . . . . 21

Technical issues . . . . . . . . . . . . . 22 
Environmental controi............... 23

Activities Plan . . . . . . . . . . . . . . 24

Deliverables... . . . . . . . . . . . 26

Schedule....................... . 26

Resources and Organization... . . . . . . . . . 28

PRELIMINARY OUTLINE OF EXECUTION PHASE FINAL REPORT . • . . • . . 29

SELECTED BIBLIOGRAPHY ON ATMOSPHERIC FLUIDIZED-BED

COMBUSTION . . . . . . . . . . . . . . . . . . . . 32

AFBC PROJECTS AND TEST FACILITIES . . . . . . . . . . . . . 36 


\section{ACKNOWLEDGMENTS}

The assistance of C. W. Di Bella, DOE Project Manager, in formulating this study and expediting its initiation is appreciated.

Neil Coates, principal contact within MITRE Corporation, METREK Division, was particularly helpful in supplying recent background material for atmospheric fluidized-bed combustion and in arranging for an early meeting of the various ORNL, DOE, and MITRE project participants during the Fifth International Conference on Fluidized-Bed Combustion. Mike McKimmey of the Engineering Societies Commission on Energy, Inc., also provided valuable assistance in obtaining information on economic ground rules from recent systems analysis studies. 
THIS PAGE

\section{WAS INTENTIONALLY LEFT BLANK}




\begin{abstract}
Early in December 1977, ORNL was asked to undertake a systems analysis and technology assessment of atmospheric fluidized-bed combustion (AFBC).

The baseline study of this activity was performed during December 1977 and is culminated in this report. The report identifies the major issues and questions regarding $\mathrm{AFBC}$, surveys available literature, proposes a work plan for a six-month execution phase of the project, presents a preliminary outline of the execution phase final report, and identifies major current AFBC projects along with issues being addressed by each.
\end{abstract}




\section{SYSTEMS ASSESSMENT OF ATMOSPHERIC FLUIDIZED-BED COMBUSTION:}

\section{BASELINE STUDY}

J. E. Jones Jr. L. E. McNeese G. Samuels
M. Siman-Tov
H. D. Cochran
T. G. Godfrey
R. E. Kuhlmann

\section{INTRODUCTION}

Early in December 1977, ORNL.was asked to undertake a systems analysis and technology assessment of atmospheric fluidized-bed combustion (AFBC) with specific emphasis on

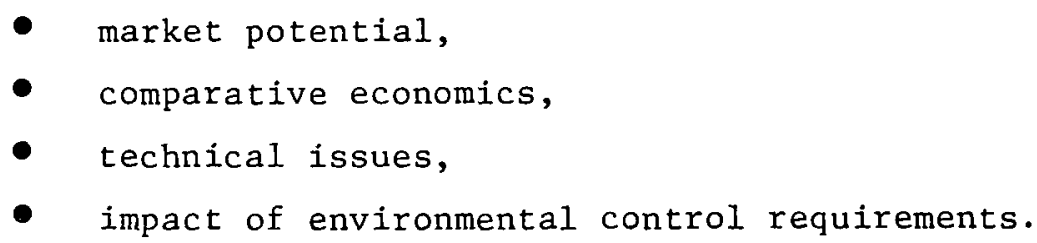

The baseline study of this activity was performed during December and culminated in the present draft report on December 30, 1977. The purpose of this report is to identify the major issues and questions regarding $A F B C$, survey available literature, propose a work plan for the six-month execution phase of the project beyinning January 1, 1978 , present a preliminary outline of the execution phase final report, and identify major current $A F B C$ projects and issues being addressed by each. Discussion of questions and problems for any technology can easily produce a very negative tone which may be interpreted as being pessimistic. The following discussion is not intended to imply that large AFBC systems cannot be built and operated reliably. It should imply, however, that it would be difficult to optimize or accurately predict the performance of a large system at the present time.

There are two approaches that can be taken in developing a new technology. One is a very systematic approach in which a large data base is accumulated from small-scale testing before progressing to larger, more expensive units. However, even this cautious approach will probably suffer a few unpleasant surprises during the process of scale-up to larger size. 
A second, more bold approach is to overlap the later part of the small-scale testing with the operation of larger systems. There are several advantages to this approach. One is that commercial introduction of the technology can be accelerated. Also, there are almost always some questions that can be answered only with large units. Furthermore, with good foresight and planning, this approach can reduce the total development cost for the new system. The most difficult aspect of this approach is to sense the proper time for beginning the large-scale testing. 


\section{MAJOR ISSUES AND QUESTIONS}

There are a number of major issues and questions regarding AFBC systems. These include economics relative to competitive systems, the impact of environmental control requirements, materials of construction considerations, the need for a simpler and more reliable fuel feed system, system control and instrumentation, boiler efficiency, overall system efficiency, and the need for an adequate data base with which to fully evaluate AFBC potential. Although the need for an adequate data base is listed last, it is the underlying concern that impacts all other issues.

\section{Market Potential}

One of the clearest issues facing AFBC at this time is the question of whether there is really a market for the technology and whether there is an industry willing to take the risks of marketing a new coal combustion technology.

Preliminary indications show a slight potential cost advantage for $A F B C$ relative to pulverized coal-fired boilers equipped with flue-gas desulfurization in typical utility sizes under current EPA regulations. This may not yield sufficient incentive to justify the risk of commercializing a new technology. If pressurized fluidized-bed combustion $(P F B C)$ is to be expected just a few years later with greater economic potential, as is suggested by some, the utility market for AFBC may not develup.

Much of the potential industrial market appears to be associated with existing facilities. For small industrial applications the equipment and facilities for coal receiving, storage, and handing and solid waste disposal become a dominant factor in terms of both cost and space. Many industrial sites do not now have sufficient land for coal handling and storage facilities. Indications are that $A F B C$ is not competitive with conventional oil-fired industrial boilers smaller than about $200,000-1 \mathrm{~b} / \mathrm{hr}$ steam for current environmental standards. ${ }^{*}$ However, AFBC does appear to

\footnotetext{
*'Item 2 in Selected Bibliography.
} 
be competitive with pulverized coal-fired boilers with scrubbers in industrial sizes. ${ }^{*}$

This is not to say that there is no market for $A F B C$, but rather that the market must be evaluated carefully, based on current cost projections, presently perceived technological assets and liabilities, and potential for meeting current and projected environmental regulations. As a technology nears the marketplace a more realistic assessment of its potential can be made; a broad-based, realistic assessment of the market potential for $A F B C$ is now required.

\section{Comparative Economics}

The basic question concerning the viability of AFBC systems is probably economic performance relative to competing systems. There are two principal questions involving economics: namely, what is the total capital cost of a given $A F B C$ system and what is the cost of energy from an AFBC system relative to competitive technologies.

Estimating the capital cost of any facility based on new technology is difficult, and the AFBC system is no exception. This difficulty stems largely from the absence of a sufficient data base containing information on which to base design decisions and to optimize a given plant design. The establishment of realistic assumptions, such as projected fuel costs and emissions standards, on which to base a plant design is a second important requirement. For example, a low fluidizing velocity through a bed will probably lead to better combustion efficiency, higher sulfur retention, higher bed heat transfer coefficients, and a decrease in particulate carry-over. However, a lower fluidizing velocity requires a larger bed cross-sectional area and a larger furnace, and will aggravate problems àssociated with the fuel feed and start-up systems. Also, deeper beds will enhance both combustion efficiency and sulfur retention, but will increase the combustion system pressure loss and thus power requirements for the combustion-air fan. Although a few partial systems studies to evaluate the relative importance of and trade-off between these parameters have been carried out, the validity of the results is limited by

\footnotetext{
"Item 5 in Selected Bibliography.
} 
the data available for the evaluations and the lack of a consistent and realistic set of underlying assumptions.

The economic viability of the AFBC technology must be evaluated in relation to competitive technologies. For relatively near-term utility applications, the most important competing technology is conventional pulverized-coal-fired plants equipped with stack-gas scrubbers. The potential importance of coal beneficiation in both conventional coalfired plants and AFBC systems must also be taken into account. For industrial applications, coal gasification should be considered a competing technology. Finally, it should be realized that any future decision to utilize AFBC will also involve consideration of PFBC because of potentially greater economic advantages. There are, of course, a number of advanced power conversion systems under development, including high-temperature gas turbines, fuel cells, magnitohydrodynamics (MHD), and alkali-metal-vapor topping cycles. However, evaluation of these advanced concepts is a major task in itself, and these advanced concepts will be excluded from the current review and evaluation of the AFBC technology.

For an economic comparison between an AFBC system and a competitive system to be most meaningful, it must be based on complete plant designs for both systems. Because $A F B C$ is a new technology with an incomplete data base, sensitivity studies for determining the effects of the more important system parameters should be included. In addition, all of the probable modes for AFBC deployment should be considered. These include large utility systems, industrial cogeneration systems of an intermediate size, and small systems for supplying heat for industrial or institutional applications which might also be of a cogeneration design.

In each case, realistic assumptions concerning possible applications are of high importance. The recommendations from an earlier study ${ }^{*}$ regarding economic evaluations for utility applications bring out these points and are as follows: "We therefore conclude that before any economic comparison of a fluidized bed system to a conventional system is made, the following be done:

\footnotetext{
* Item 8 in Selected Bibliography.
} 
1. All design comparisons should be of full scale (600 to 800 megawatt) systems. This will ensure that the complexity of controls and feed systems are thoroughly understood.

2. A complete conceptual design for the fluidized bed system must be developed. This should identify optimistic, realistic and pessimistic conditions. For example, with respect to the $\mathrm{Ca} / \mathrm{S}$ ratio: optimistic is probably 1.5 , realistic is 2.5 , and pessimistic is 4.0. This type of evaluation must be made for the total process.

3. A complete design for a conventional system must be made. 4. Comparisons must be made for a total plant including land, structures, fans, etc. This is the only completely reliable way to ensure that the comparison is valid and that we are not comparing dissimilar parts."

Similar bases for other AFBC deployment modes must also be developed.

Technical Isoues

A number of important technical issues are of concern for AFBC systems. These are discussed below under the general headings of solids handling, system control and instrumentation, boiler thermal efficiency, overall system efficiency, materials, and data base and predictive models.

\section{Solids handling systems}

Fuel feed system. The solids feed system is one of the more critical and difficult mechanical features of an AFBC system. Uncertainties in this area are related not only to the mechanical aspects of the system but also to their effect on sulfur retention, the combustion process, and the potentially adverse effect on the corrosion of bed tube materials under reducing conditions. To perform its intended function, the solids feed system must introduce reliably a metered amount of coal and limestone to the furnace and must feed the coal in a manner 
such that combustion takes place predominately within the bed so that the resulting $\mathrm{SO}_{2}$ can come into contact with the CaO. Also, to minimize materials corrosion problems, the coal and limestone must be fed in a manner that prevents reducing zones, or alternating reducing and oxidizing zones, in the volume of the bed containing the boiler or steam tubes.

Coal is normally fed to the bottom of a fluidized bed either through ports in the bottom support plate or through tubes, or lances, from the sides of the furnace. One question concerning either of these feeding methods is the number of feed points required. One rule of thumb often quoted states that one feed point should be provided for each $9 \mathrm{ft}^{2}$ of bed area. Actually, the number of feed points required probably depends on many factors. The criterion that should be applied is that the coal be burned in such a manner that local hot zones or reducing zones are not produced in the tube matrix volume of the bed. For example, if the particle size of coal, fed to a furnace is very small, combustion would be very rapid and occur near the feed point. Thus the required number of feed points would be large. Conversely, if very large lumps of coal are fed to a bed, the coal would tend to remain near the feed point until it is reduced sufficiently in size by combustion to be fluidized. This, in turn, could lead to reducing conditions near the feed points. Another factor to be considered is the vertical distance between a coal feed point and the tube matrix. Increases in this distance favor dispersion of the coal throughout the bed material before it contacts the tube matrix and reduce the probability of a reducing zone in the matrix. Reliable models for predicting combustion, mixing rates, and reaction conditions within large fluidized beds are needed.

One can attempt to avoid coal feed system problems by overdesign that is, by providing a large number of feed points. However, the resulting solids feed system will be expensive, and the larger number of feed points can add other problems. To minimize the cost of the feed system, most designs use a system in which a metered amount of coal is split several times before entering the furnace. This splitting system could lead to an unacceptably nonuniform feed rate or particle size distribution of coal to various sections of the bed. For example, if the coal feed is 
split three times with an accuracy of $\pm 5 \%$ each time, the resulting coal feed rate to the feed points could vary by as much as $\pm 16 \%$.

Precautions are also required in the design of lines supplying coal to the feed points, especially if long pipes are used to carry the coal through the furnace wall and bed to the feed points. In this case, the coal may be heated to a temperature which could cause coking and result in eventual plugging of the feed lines.

One coal feeding method being proposed (with probable installation in the Rivesville plant) uses a spreader stoker to spread the coal over the surface of a bed. The success of this method will probably require that coal fines be eliminated or kept to a small fraction of the coal fed, since the fines would burn in the freeboard above the fluidized bed with escape of the resulting $\mathrm{SO}_{2}$ from the furnace. Also, this system could result in excessive carry-over or elutriation of unburned carbon from a bed. The main attraction of this coal feeding system is lower cost and the probable elimination of coal dryers.

Ash and spent-sorbent handling system. The ash and spent-sorbent handling system is not as critical as the fuel feed system; however, there are several aspects of the system that must be proven in large installations. Included in this category are the location and number of drain ports required in a bed and methods for handling and recovering heat from the hot solids drained from a bed; methods of reinjecting fly ash into a furnace to recover the heat content of unburned carbon elutriated from a bed; and, if bed level is varied for load control, a method for transferring, storing, and reinjecting the bed material.

System control and instrumentation

System control. There are several characteristics of fluidized-bed steam boilers that lead to rather unique start-up and control problems. For best sulfur retention in an atmospheric-pressure bed, with either limestone or dolomite as the sulfur sorbent, the bed should operate in the range of 1450 to $1550^{\circ} \mathrm{F}$ ( 788 to $844^{\circ} \mathrm{C}$ ) because the sulfur retention efficiency (especially with limestone) decreases significantly as the temperature is increased or decreased from this range. 
Control of the system is complicated by the heat transfer characteristics in the bed and in the tubes. The heat transfer coefficient between the bed and the tube wall is high - around 50 to $60 \mathrm{Btu} / \mathrm{hr} \cdot \mathrm{ft}{ }^{2} \cdot{ }^{\circ} \mathrm{F}$ $\left(\sim 300 \mathrm{~W} / \mathrm{m}^{2} \cdot \mathrm{K}\right)$. At the same time, the heat transfer coefficient from the tube to water boiling under nucleate boiling conditions is very high of the order of $5000 \mathrm{Btu} / \mathrm{hr} \cdot \mathrm{ft}^{2} \cdot{ }^{\circ} \mathrm{F}\left(\sim 28,000 \mathrm{~W} / \mathrm{m}^{2} \cdot \mathrm{K}\right)$. Thus the tube wall operates at a temperature near the water temperature. Both the combustion-side and the water-side coefficients are essentially independent of the combustion gas and water flow rates respectively. The heat flux is equal to the product of the overall heat transfer coefficient and the temperature difference between the bed and the water; since the overall heat transfer coefficient is essentially constant, a reduction in the rate of heat release in the bed will result in a reduction in the bed temperature which produces two undesirable effects. The first is a loss in sulfur retention efficiency because the $\mathrm{SO}_{2}$ sorption reaction rate is highly temperature sensitive. Secondly, at about $1000^{\circ} \mathrm{F}\left(538^{\circ} \mathrm{C}\right)$ the bed will quench - that is, "the fire will go out." If the coal feed is continued, coke may form and clog the bed. Also, if the coal feed is continued at a low bed temperature, an excessive amount of combustible material may build up in the bed which could lead to excessive temperatures and severe reducing conditions once the bed is reignited.

If the water flow to the boiler is reduced in an effort to keep the bed temperature constant at reduced heat output at $1500^{\circ} \mathrm{F}\left(816^{\circ} \mathrm{C}\right)$, the water-side heat transfer mechanism shifts from nucleate boiling to film boiling with a significant decrease in overall heat transfer coefficient. For example, if one attempts to reduce the heat flux from the bed to the tube wall by allowing the tube wall temperature to increase to $1000^{\circ} \mathrm{F}$ $\left(538^{\circ} \mathrm{C}\right)$, the heat flux will be cut roughly in half, but the heat transfer mode will be via film boiling, which will be very unstable and will lead to wide fluctuations in the local metal temperature. Even worce, the water flow rate through the tube will become highly unstable, and this, in turn, can lead to even more severe temperature fluctuations and thermal stresses. Thermal strain cycling failure of the tubes may result or the tubes may overheat to the point that loss in strength leads to failure from pressure stresses. 
For good reliability, operation must be constrained to the nucleate boiling regime with a fixed bed temperature of around $1500^{\circ} \mathrm{F}\left(816^{\circ} \mathrm{C}\right)$. Basic heat transfer considerations indicate that the only practical way in which the heat input to the boiler can be reduced is to reduce the amount of surface area of the tube matrix immersed in the bed. This, in turn, implies that either the bed should be compartmentalized so that the heat output can be changed accordingly or the level of the fluid bed should be varied. The former approach presents difficulties in the relative phasing of the flow of feedwater to a bed as it is being reactivated. Unless phasing is carried out properly, one runs the danger of quenching the bed or producing film boiling, generating hot spots in the tubes and subjecting the tubes to severe thermal cycling.

Varying the bed depth presents a problem in that it is difficult to determine the location of the bed surface during operation because, in the preferred operating regime, the bed will be bubbling violently. For an atmospheric fluidized bed where bed depth may be limited to about 40 to 60 in. for an "acceptable" pumping power loss, the uncertainty in bed depth would be about $10 \%$ at full power and a progressively larger fraction if the bed depth were reduced at part load.

Instrumentation. Instrumentation for determining bed depth and combustion gas composition is needed. Because of the sensitivity of materials of construction to reducing conditions, combustion gas analysis should be rapid and on-line.

Boiler, thermal efficiency

There are several features of an AFBC system that may lead to different types of system energy losses or that have the potential for causing losses higher than those of conventional systems. These factors include the endothermic chemical reaction associated with calcination of limestone in the bed at high $\mathrm{Ca} / \mathrm{S}$ ratios, the sensible heat lost in solids rejected from the plant, and the loss of unburned carbon. These energy losses are probably no greater than those associated with flue-gas desulfurization with flue-gas reheat to $275^{\circ} \mathrm{F}\left(135^{\circ} \mathrm{C}\right)$. 
Chemical reactions. The chemical reactions involved in sulfur fixation are both an endothermic calcination and an exothermic sulfation reaction. The net thermal effect of these reactions will depend on the sulfur content of the coal and the $\mathrm{Ca} / \mathrm{S}$ ratio required to meet emission standards for $\mathrm{SO}_{2}$. For example, with a high-sulfur coal ( $4 \%$ ) and the use of limestone at a feed rate to produce a $\mathrm{Ca} / \mathrm{S}$ ratio of 2.5 , the quantity of heat released is about equal to that absorbed. However, for a $\mathrm{Ca} / \mathrm{S}$ ratio in the range of 4 to 5 , the quantity of heat absorbed is greater and would amount to 1 or $2 \%$ of the heating value of the coal. It should be noted that if dolomite is used as the sorbent, the $\mathrm{MgCO}_{3}$ will also be calcined. However, the Mgo does not react with sulfur, and, with the same $\mathrm{Ca} / \mathrm{S}$ feed rate, energy loss via the calcination reaction will be greater.

Sensible heat losses. The total amount of waste solids, and thus the potential for thermal energy loss in this stream, will depend on the ash and sulfur content of the coal and the amount of sorbent material required for sulfur retention. Solids are rejected from the combustion system at three locations: the furnace, the cyclone separators, and the final stack-gas cleanup system (probably a bag house). Most of the material will be rejected from the furnace and the cyclone separators. Although many factors affect the potential thermal losses at these points, under the worst conditions and with the assumption of no heat recovery from the waste solids, energy losses in the range of 1 to $2 \%$ of the heating value of the coal. would probably result. $\bar{B} y$ cooling the solids to 300 to $400^{\circ} \mathrm{F}\left(149\right.$ to $205^{\circ} \mathrm{C}$ ) and returning the recovered heat to the system, these losses can be reduced to well under $0.5 \%$ of the heating value of the coal.

Carbon losses. Energy is also lost from a system in the form of unburned carbon. Carbon can be lost by two paths: in solids drained from the furnace and in particulate material elutriated from the beds. The solids drained from the beds will contain about the same fraction of carbon as that existing in the bed during normal operation. This value 
will probably be about $1 \%$, and the energy lost by this path would be a few tenths of $1 \%$ of the heating value of the coal.

The amount of carbon elutriated from the bed depends strongly on the velocity of the combustion gases leaving the bed. For systems operating with a high superficial velocity [>10 $\mathrm{fps}(3 \mathrm{~m} / \mathrm{sec})]$, the amount of carbon carried from the bed may reach $15 \%$ of the coal feed rate. Losses of this magnitude impose a significant penalty, and the elutriated material must be collected by cyclone separators and recycled through a separate carbon burnup cell which operates at a higher temperature [up to $\left.2000^{\circ} \mathrm{F}\left(1094^{\circ} \mathrm{C}\right)\right]$. Thus the loss of carbon by this path depends not only on the amount of material elutriated from the beds, but also on the efficiency of the cyclone separators and the efficiency of the burnup cells for utilizing the recycled material.

The total energy loss via unburned carbon depends on a number of system design parameters. A reasonable system design should keep this loss to less than $2 \%$ of the heating value of the coal.

\section{Overall system efficiency}

One concern expressed about AFBC systems is that the maximum operating temperature of the tluidized bed is limited to 1750 to $1800^{\circ} \mathrm{F}$ (955 to $983^{\circ} \mathrm{C}$ ) by equilibrium considerations for the chemical reactions that retain the sulfur within a bed. This compares with a maximum combustion temperature of about $3500^{\circ} \mathrm{F}\left(1927^{\circ} \mathrm{C}\right)$ for other conventional fossil-fired systems. Since the maximum theoretical effirienry of a heat power cycle depends on the upper and lower temperature of the cycle, the AFBC system might appear to have a much lower theoretical thermal efficiency than a conventional combustion system.

The maximum theoretical thermal efficiency depends on the temperature of the cycle working fluid and not on the combustion temperature, however. Current power system efficiencies are limited by materials of construction and not combustion temperature. Also, the achievable efficiency depends on other factors such as the effectiveness of heat exchangers, the type of power cycle, and the efficiency of power conversion devices. The 
fluidized-bed concept will not suffer any significant efficiency penalty in comparison with higher-temperature combustion systems until materials and advanced power conversion devices are developed that utilize higher combustion temperatures.

\section{Materials}

An AFBC potentially imposes severe conditions on the various components of the system because of the severe consequences of reducing conditions on materials of construction. However, the only part of the $A F B C$ that is truly unique in this respect is the fluidized bed, since, above the bed, the plant resembles closely a conventional pulverizedcoal steam boiler. The areas of concern then are in-bed heat exchanger tubes, air distributor plate or grid, side walls, coal feed lines and nozzles, spent-bed removal hardware, and possibly the cyclones that return elutriated material to the carbon-burnup cell. Actually, the above-bed materials in an AFBC will probably experience a less severe environment than those in a conventional steam plant, since the lower combustion temperature yields a much lower concentration of vaporized alkali-metal and alkaline-earth compounds.

In-bed heat exchanger tubes. Corrosion and erosion of in-bed tubes will depend strongly upon particular design features. Reducing or cyclic reducing-oxidizing conditions must be avoided for the tubes to have reasonable lifetimes. Cr-Mo steels, Incoloy 800, and 300-series stainless steels are likely candidates for evaporator or superheater in-bed tubing, but the tolerance of these materials to off-design local environments has not been established. Erosion of tubes can be minimized by proper design for reasonable local particle velocities. These velocities, however, are not well defined: superficial velocities are normally specified and do not necessarily define local conditions. Also, jet impingement from nozzles must be avoided. Erosion must be controlled by design and verified by tests to ensure that the oxide scale is protective of the tube wall. 
Air distributor plate. This component is critical to the operation of the AFBC, since its performance and integrity in large measure dictate local bed characteristics. Materials are not necessarily limiting in this application, since a variety of alloys and/or ceramics are available. Rather, engineering design of this portion of an AFBC will determine performance.

Side walls. Proper regard for local conditions must be provided during design. A variety of alloys and/or refractories are applicable, but must be qualified for the particular design. A potential problem exists in the vicinity of penetrations in the side walls where conditions could be stagnant and reducing. Catastrophic hot corrosion of alloy tubes has been observed in an AFBC where the tubes passed through a refractory wall and experienced a locally reducing condition.

Coal feed lines and nozzles. Of the two possible methods for introducing coal to an AFBC (spreader stokers and in-bed feeders), the in-bed feeder type has potential materials problems. The atmosphere surrounding the nozzle or injection tube is potentially reducing and deserves special consideration to avoid sulfidation. Considering the large number of coal feed points, this is an area that must be carefully evaluated through experiments and long-time testing. A failure in a feed nozzle could accentuate bed inhomogeneity with undesired consequences for other components.

Spent-bed removal hardware. Problems in this area are very design dependent. With the possible exception of valves that might be required to handle the hot, abrasive bed material, suitable materials are avail.able for this application. As in the other areas cited above, locally reducing or cyclic atmospheres could be catastrophic. The problems of valves for hot and abrasive solids is not unique to AFBCs and is a severe materials difficulty. No totally acceptable solution is at hand. Design innovations may eliminate the need for valves operating with hot, abrasive solids. 
Cyclones. The problem with regard to cyclones is one of erosion and corrosion of the internals and is well documented. The AFBC application is more severe than usual, however, because of the elevated temperatures and will require special attention.

Materials summary. No insurmountable materials problems are foreseen for AFBC systems provided that reducing environments are avoided, but many problem areas require careful invastigation. In general, the limits of available materials will place constraints on design criteria and operating parameters in AFBC systems. The tolerance of the various components to anticipated off-specification local conditions must be ascertained through controlled experiments in order to establish proper operational constraints.

\section{Data base and predictive models}

One of the basic and typical problems of applying any relatively new technology is the lack of a good technical data base and predictive models. For AFBC systems there are some rules of thumb, "ball-park" estimates, and a quantity of conflicting results, or, perhaps, conflicting conclusions drawn from these results. In order to optimize or reliably predict the performance of a given AFBC system, correlations are needed that relate the effects of the various system parameters to sulfur retention efficiency, combustion efficiency, heat transfer coefficient, attrition rate of the sorbent material, elutriation of bed material, size of elutriated material, etc. The problem is further complicated in that both the coal and sorbent properties may be highly dependent on their sources.

The accumulation of an adequate data base would be facilitated by a systematic evaluation of selected parameters. Also, an information conter to accumulate and/or analyze the information could make it more easily available. 
Environmental Control

The environmental issues important to an evaluation of AFBC technology include the emissions of $\mathrm{SO}_{2}$, $\mathrm{NO}_{\mathrm{x}}$, particulates, and the disposal of solid wastes, with particular attention to the behavior of heavy metals and free lime. The principal reason for the current high interest in fluidized-bed combustion is the potential of these systems to reduce emissions of both $\mathrm{SO}_{2}$ and $\mathrm{NO}_{x}$. The effect of the more stringent requirements being considered for the reduction of emissions tor $\mathrm{SO}_{2}$ (90\% reduction in emission in the range 0.2 to $1.21 \mathrm{~b}$ per million Btu with a maximum release of 1.2 lb per million $\mathrm{Btu})$, $\mathrm{NO}_{\mathrm{x}}(0.6 \mathrm{lb}$ per million Btu), and particulates (0.03 $1 \mathrm{~b}$ per million Btu) will place an added burden on both the AFBC and competitive systems. Studies to evaluate the impact of tighter requirements on the relative economic and technical aspects of AFBC and competing systems are needed.

Both the existing standards for stack-gas emissions and the proposed New Source Performance Standards are formulated largely in terms of specific emission limits for particular pollutants $\left(\mathrm{SO}_{2}\right.$, $\mathrm{NO}_{\mathrm{x}}$, and particulates) and were formulated with pulverized-coal-fired plants in mind. To the extent that effects from individual pollutants can be considered additive, it may be more reasonable to formulate emission standards in a similar manner. If such were the case, the inherently low NO emission levels associated with AFBC operation may allow some relaxation in the absolute emission level for $\mathrm{SO}_{2}$ or particulates. This idea will require much further study before its full significance can be evaluated, however.

$\mathrm{SO}_{2}$ emissions

Small-scale tests have shown the technical feasibility of meeting current $\mathrm{SO}_{2}$ emission standards of $1.2 \mathrm{lb}$ per million Btu with practically all U.S. coal. There are, however, obvious limits to the ability of an AHBC system, or competitive systems, to reduce emissions. More stringent emission standards will require the use of more sorbent material and/or beneficiation to reduce the amount of sulfur in the coal fed to a furnace. Evaluation of the impact of more stringent standards on AFBC systems is 
hampered by the lack of an adequate AFBC model and the associated data base for predicting sulfur retention in a fluidized bed. Presently, a large number (19) of parameters are known or are theoretically suggested to affect the retention of sulfur in a fluidized-bed combustor.

$\mathrm{NO}_{\mathrm{x}}$ emissions

The relatively low combustion temperature of an AFBC system favors inherently low $\mathrm{NO}_{\mathrm{x}}$ emission rates. Most of the $\mathrm{NO}_{\mathbf{x}}$ formed in fluidized beds is attributed to the bound nitrogen present in the fuel. In general, $\mathrm{NO}_{\mathrm{x}}$ emissions from AFBC systems should be well below the current standard of $0.7 \mathrm{lb}$ per million Btu, and have been shown experimentally to be about one-half of this limit in many cases. Thus a small reduction in $\mathrm{NO}_{\mathrm{x}}$ emission standards should not be difficult for AFBC systems to meet. The quantity of $\mathrm{NO}_{x}$ formed appears to increase with an increase in the amount of excess air used in the combustion process. However, the excess air would normally be controlled at as low a level as possible to minimize heat losses in the stack gases.

\section{$\underline{\text { Particulate emissions }}$}

The combined effects of particle attrition and elutriation in an $A F B C$ result in the production of finely divided particles which would be released to the environment without an effective trapping system. Although AFBC systems would normally use cyclone separators to reduce the amount of particulate material entrained from the beds, additional cleanup, either with electrostatic precipitators or bag filters, will be needed to meet the current emission standard of $0.1 \mathrm{lb}$ per million Btu. The use of electrostatic precipitators for this application is questionable, since the electrical resistivity of the particulate material must be in a limited range for these devices to be effective. Limestone or dolomite as well as the products resulting from $\mathrm{AFBC}$ operation ( $\mathrm{CaO}, \mathrm{MgO}, \mathrm{CaSO}_{4}$ ) have very high resistivities and may make the precipitator ineffective.

\footnotetext{
${ }^{*}$ Item 8 in Selected Bibliographỳ.
} 
Bag filter systems should be satisfactory for this application. If lower than current emission standards are adopted, a filter fabric having a lower porosity than currently used may be required, which will increase the required fabric area or fan power requirements or both.

Although there is growing concern about the presence of trace elements in the particulate fraction of the stack gases from an AFBC, only limited data are available on this subject. The extent or severity of the problem is not known. Additional information is needed on this subject before it can be fully evaluated.

\section{Solids disposal}

The quantity of solids produced by an AFBC plant will depend on several factors. In general, the amount of material will be in the range of two to four times the ash content of the coal which is rejected from conventional plants. For a plant in which limestone is used as the $\mathrm{SO}_{2}$ sorbent, the additional material will be primarily $\mathrm{CaO}$ and $\mathrm{CaSO}_{4}$. Ideally, a useful application for this material might be found, and studies to date have indicated that the material is suitable for agricultural and/or industrial purposes. However, in many cases, it will be necessary to dispose of the solids.

Disposal may be complicated by several factors. A potential problem is caused by the $\mathrm{CaO}$, which can result in an excessive $\mathrm{pH}$ in water coming in contact with the material. Another potential problem is associated with leaching of heavy elements from the solids. The impact of this problem depends heavily on the final implementation criteria and standards for the recently passed Resource Conservation and Recovery Act of 1976 (KCKA). Although the full scope and meaning of the act are still uncertain, it is clear that the RCRA is the equivalent for solid wastes of the Clean Air Act for air emissions and the 1972 Amendments to the Federal Water Pollution Control Act for water emissions.

The total quantity of solids rejected from the plant can be reduced if the sorbent material can be regenerated and reused. However, the technical and the economic feasibility of regeneration have yet to be proven. 
WORK STATEMENT FOR EXECUTION PHASE

OF

AFBC SYSTEMS ANALYSIS AND TECHNOLOGY ASSESSMENT

Objective

The objective of this project is to carry out a systems analysis and technology assessment for atmospheric fluidized-bed combustion with specific emphasis on

1. market potential,

2. comparative economics,

3. technical issues,

4. impact of environmental control requirements.

Background and Justification

The evolving national energy policy based on increased use of coal to satisfy the national energy needs on the one hand and increasingly stringent environmental constraints on the other hand have made atmospheric fluidized-bed combustion a serious contender for replacing conventional yas and oil energy conversion systems. There are, however, many unanswered questions related to AFBC technology. The most obvious question is to what extent can this technology simultaneously utilize high-sulfur coal, meet the existing or proposed environmental constraints, and be economically competitive with alternative coal combustion systems? Another important general question is to what kind of application is AFBC technology presently attractive and what kind of development programs are needed to make it attractive for other applications that appear promising?

This work plau is meant to outline an effort tn address these and other questions and to collert in one document a base of information which will help DOE Fossil Energy (DOE/FE) managers in making critical decisions concerning $A F B C$ technology. This project will evaluate the state of the art in $A F B C$, assess the technology in the light of emerging environmental guidelines and competing systems, and identify R\&D needs. 
The effort outlined represents the execution phase of a continuing systems analysis and technology assessment activity in support of AFBC development. The scope of work for the subsequent follow-on phase will be defined during the first three months of the execution phase.

\section{Proposed Approach}

A team of scientists and engineers has been formed from various ORNL divisions and UCC-ND Engineering to provide a broad background of expertise in chemical technology, component and hardware development, heat transfer and fluid dynamiss, materialo; control dill iustrumentation, safety, environmental sciences, engineering analycio, and economics.

The activities of the systems analysis and technology assessment cffort will include

1. Literature survey and review;

2. direct contacts and communications with $A F B C$ analysis, design, development, and research activities in progress, including visits to existing AFBC facilities;

3. analysis of data and information collected in relation th the areas of concern previously identified, resulting in (a) a statement of the state of the art, (b) iderilification of principal AFBC markets, (c) projection of economic potential of AFBC relative to alternatives, (d) identification of problem areas and their categorization in terms of state of resolution, (e) programmatic recommendations regarding unresolved areas of concern, (f) recommendations regarding future direction and emphas1s in AFBC Lechnology development, and ( $g$ ) reporting and documentation.

In all of the above activities, full utilization will be made of available information from all existing programs. ORNL will coordinate activities within this project with ongoing efforts at the MITRE Ccrporation (METREK Division) and TRW Corporation, Inc., and will draw from their $A F B C$ experience. In addition, ORNL will utilize consultants and other subcontractors as appropriate. 
Areas of Investigation and Emphasis

The systems analysis and technology assessment will be concerned with the overall AFBC technology program and will consider utility, industrial, and institutional applications. The principal areas of investigation are as follows:

1. market potential,

2. comparative economics,

3. technical issues,

4. environmental control.

The scope of investigation in each of these study areas is outlined below.

Market potential

The various potential AFBC applications will be identified and investigated. This will include use of AFBC to produce heat and/or heat and power in cogeneration systems for industrial and institutional applications. Power generation in utility applications will be studied in relation to alternate technologies.

The potential market for each AFBC application will be evaluated, keeping in mind the constraints imposed by competing systems. Specific attention will be given to the timeliness of AFBC development in light of the emerging PFBC technology. The investigation will be based on existing information from past and current studies and supplemental contacts with development activities.

\section{Comparative economics}

Economic comparisons of AFBC to conventional coal combustion in both utility and industrial boilers will be performed. Capital, operation and maintenance, and fuel cost estimates will be developed based on data available at ORNL as well as data drawn from other DOE and TVA studies. The cost elements of capital, O\&M, and fuel will be combined to estimate total energy cost. Sensitivity studies will be made in relation to the range of estimates obtained in. the data-gathering activity, the 
uncertainties within the estimates, the effects of coal and limestone types and costs, and the impacts of present and anticipated environmental regulations.

The specific comparisons that will be performed are as follows:

1. For utilities, comparison will be made, in the size range of 570 to $800 \mathrm{MW}(\mathrm{e})$, between $\mathrm{AFBC}$ and a conventional pulverizedcoal-fired boiler with scrubber. Some consideration will be given to PFBC costs if sufficient information is available.

2. For industrial applications, comparisons will be made for

(a) small boilers in the size range of $50,000-$ to $100,000-1 \mathrm{~b} / \mathrm{hr}$ steam;

(b) large boilers in the size range of $250,000-$ to $500,000-1 \mathrm{~b} / \mathrm{hr}$ steam.

For the small industrial applications, comparison will be made between $A F B C$ and coal gasification (using a commercially available gasifier). For the large industrial applications, comparison will be made between $A F B C$ and a pulverized-coal-fired boiler with scrubber.

$\underline{\text { Technical issues }}$

The availability of technology and an adequate data base for early commercial introduction of AFBC for both industrial and utility applications will be assessed. The most critical problem areas and R\&D needs will be identified, and recommendations will. be made regarding priorities and schedule for the required $R \& D$ activities. The principal technical areas to be investigated are:

1. combustion and sorbent performance;

2. heat transfer and fluid mechanics;

3. materials (both in-bed and systems);

4. control and instrumentation (including start-up, shutdown, turndown, load following, combustion, and effluent control);

5. structural considerations (including vibrations and thermal stresses); 
6. solids handling systems and component development (including coal feed systems, cyclones, precipitators and bag houses, spent-bed material and sludge-handling systems, and other auxiliary equipment and systems);

7. safety (a preliminary failure analysis);

8. data base and predictive capabilities (including system performance models, optimization models, dynamic models, predictive and design correlations, and data base collection and retrieval).

The effects on AFBC performance of coal and sorbent types, particle size distribution, air velocity, Ca/s ratio, bed depth, freeboard height, excess air, bed temperature, and other operating parameters will be investigated and evaluated. A preliminary discussion of the major questions and issues for $A F B C$ is given in an earlier section of this report.

Full utilization will be made of all available resources through visits and direct communication with AFBC activities in progress and technology assessments performed in the past. This assessment will be performed in full coordination with another similar but separate assessment being performed by ORNL that is specifically related to a 200-MW(e) $A F B C$ demonstration plant.

\section{Environmental control}

The capability of AFBC to meet both present and anticipated environmental regulations and constraints will be investigated, and the related economic and performance impacts will be evaluated. Specific emphasis will be given to the emissions of $\mathrm{SO}_{2}, \mathrm{NO}_{\mathrm{x}}$, and particulates and the disposal of solids produced. The problem of trace elements in both stack gas and solid-waste streams will be considered, as will be any other pending environmental issues. 


\section{Activities Plan}

The following activities will be performed in order to accomplish the identified objectives of this effort:

1. Complete the literature survey and review what was performed during the baseline study phase of this project. Prepare

a selected bibliography arranged by issues and problem areas.

2. Complete a matrix of current AFBC projects and facilities, emphasizing the issues being investigated, the expected output, and schedule,

3. Prepare a list of organizations and facilities to be visited for direct communication and information gathering. Facilities and organizations to be visited include some of those in the following preliminary list:

DOE

TVA

EPRI

EPA

Burns \& Roe

Stone \& Webster

Pope, Evans and Robbins, Inc.

Foster Wheeler

Babcock \& Wilcox Company

Combustion Engineering, Inc.

Rivesville, West Virginia

Morgantown Energy Research Center

MITRE Corporation, METREK Division

TRW Corporation, Tnr..

BCURA

Exxon Research and Energy Company

Combustion Power Company

Argonne National Laboratory

General Electric

Battelle Memorial Institute

Fluidyne Engineering Corporation 
Institute of Gas Technology

Ohio State

Combustion Systems Ltd.

MIT Energy Lab

Oregon State University

4. Meet on or about January 11, 1978, at DOF headquarters to review, modify, and obtain approval. of this work plan, and discuss the input required from other organizations and facilities to be visited.

5. Coordinate a schedule for visits with DOE and the pertinent organizations.

6. Prepare a list of topics and questions related to issues and uncertainties for discussion during each visit (probably to be sent to the organizations involved before the visit).

7. Prepare on a consistent basis all information and cost data required for performing the economic comparisons.

8. Define work to be undertaken by the project after June 30 , 1978 (follow-on phase).

9. Evaluate possible AFBC applications and market potential.

10. Perform economic comparisons as outlined in the work statement.

11. Perform visits and direct discussions with the selected organ1zations to determine the state of the art of AFBC activities and solicit these organization's judgment regarding all major pending problem areas and $K \& D$ reeds.

12. Analyze all information and data collected in the previous steps and evaluate the risks involved in each problem area and the possible consequences it may have on the success and/or schedule of AFBC demonstration projects. Evaluate existing $R \& D$ programs and assess the applicability of the expected information for commercial introduction of AFBC techrology, taking into account the timing of achieving those results vs the schedule of demonstration projects. 
13. Identify those specific issues which should be addressed by R\&D programs and define the objectives and scope of each such R\&D task.

14. Prepare a document reporting all of the above activities, including final conclusions and recommendations.

\section{Deliverables}

The following deliverables will be prepared:

1. A report of status will be published in the ORNL Coal Technology Program monthly and quarterly progress reports.

2. A status report by letter will be submitted each month to the DOE project manager.

3. An oral presentation will be made to DOE personnel upon completion of the task. Two intermediate informal status presentations will be given on about March 1 and June 1, 1978 .

4. A draft proposal for work to continue after June 30 in the follow-on phase of this project will be submitted for DOE review on about April 15, 1978.

5. A draft report will be submitted to DOE for review on June 30, 1978. Final report publlcation will follow after DOE comments are received.

Schedule

The execution phase of the project will be accomplished during a period of six months beginning January 1, 1978. The execution phase is a continuation of the baseline study phase of the project which was performed during December 1977. The present report is the principal deliverable resulting from the baseline study. Follow-on phase activities, beginning on July $l$, will be defined during the first three months of the execution phase. The timetable of the activities and milestones defined in this work statement is given in Table 1. 
Table 1. Proposed timetable for execution phase of AFBC systems analysis and technology assessment

\begin{tabular}{|c|c|c|c|c|c|c|}
\hline \multirow{2}{*}{ Starting date: January 1,1978} & \multicolumn{6}{|c|}{ Months } \\
\hline & Jan. & Feb. & Mar. & Apr. & May & June \\
\hline \multicolumn{7}{|l|}{ General schedule } \\
\hline Preparation & & & & & & \\
\hline Survey and review & & & & & & \\
\hline Analysis and conclusions & & & & & & \\
\hline Reporting and documentation & & & & & & \\
\hline \multicolumn{7}{|l|}{ Detailed schedule } \\
\hline \multicolumn{7}{|l|}{ 1. Bibliography } \\
\hline \multicolumn{7}{|l|}{ 2. Projects and facilities matrix } \\
\hline $\begin{array}{l}\text { 3. List of organizations and sites } \\
\text { to be visited }\end{array}$ & & & & & & \\
\hline 4. Technical advisory committee review & $\diamond$ & & & & & \\
\hline 5. Visiting program and schedule & & & & & & \\
\hline $\begin{array}{l}\text { 6. List of topics and questions } \\
\text { for discussion }\end{array}$ & & & & & & \\
\hline 7. Preparation of cost data & & & & & & \\
\hline 8. Prepare proposal for follow-on phase & & & & & & \\
\hline 9. Applications and market potential & & & & & & \\
\hline 10. Economic comparisons & & & & & & \\
\hline 11. Visits and direct discussions & & & & & & \\
\hline 12. Analyze material and assess & & & & & & \\
\hline applicability of R\&D programs & & & & & & \\
\hline $\begin{array}{l}\text { 13. Identify and define R\&D tasks } \\
\text { required and recommend priorities }\end{array}$ & & & & & & \\
\hline $\begin{array}{l}\text { 14. Prepare draft report with summary } \\
\text { and recommendations }\end{array}$ & & & & & & \\
\hline
\end{tabular}


Resources and Organization

This project will be a combined effort involving DOE, ORNL, MITRE, TRW, and ESCOE, with ORNL having lead responsibility. ORNL will, as necessary, subcontract with additional organizations and will utilize to the extent possible the results from ongoing AFBC studies. Expected involvement and input from organizations other than ORNL will include the following:

MITRE

Bibliography (activity 1)

AFBC program and facilities (activity 2)

Review and comments as reçuested

- General support

Total effort of about 4 man-months

TRW

Applications and market potential (activity 9)

- Solid-handling systems and component development

- Review and comments as requested

- Genera1 support

Total effort of about 4 man-months

$\mathrm{UE} \& \mathrm{C}$

- Assist in compilation and normalization of cost data

[UE\&C (United Engineers \& Constructors)]

Total cost of about $\$ 40,000$

The total cost for the baseline study phase and the execution phase of the project is anticipated to be about $\$ 400,000$ and will provide about 60 man-months of effort and the estimated UE\&C subcontract cost of $\$ 40,000$.

A DOE technical advisory committee composed of E. K. Bastress, S. I. Freedman, C. W. Knudsen, and J. S. Wilson will review and conment on the project activities and direction. C. W. Di Bella is the DOE Project Manager, and J. E. Jones Jr. is the ORNL Project Manager. 
PRELIMINARY OUTLINE OF EXECUTION PHASE

FINAL REPORT

I. INTRODUCTION
A. Background
B. Objectives
C. Approach

II. SUMMARY

III. CONCLUSTONS AND RECOMMENDATIONS

A. Critical Issues

1. Market potential

2. Comparative economics

3. Technical issues

4. Environmental control

B. Fossil Energy Program Options and Recommendations

C. Plans for Follow-on Phase Studies

IV. DISCUSSION OF ISSUES AND QUESTIONS

A. Market Potential

1. Utility

2. Industrial and Institutional

3. Miscellaneous (high-sulfur coal from beneficiation, mine tailings, municipal waste, unique applications)

B. Comparative Economics

1. Utility [570-800 $\mathrm{MW}(\mathrm{e})]$

(a) Cost comparison (AFBC vs conventional pulverized boiler with FGD)

(b) PFBC cost comparison

2. Industrial - small (50,000- to $100,000-1, \mathrm{~b} / \mathrm{hr}$ steam)

(a) Cost comparison (AFBC vs pulverized or stoker boiler with FGD and/or coal gasification with gas-fired boiler)

(b) Other comparisons

3. Industrial - large (250,000 - to 500,000-1b/hr steam)

(a) Cost comparison (AFBC vs pulverized boiler with FGD)

(b) Field vs shop fabrication

4. Sensitivity studies

(a) Environmental standards

(b) Coal type

(c) Coal cost

(d) Sorbent utilization

(e) Other (as appropriate)

C. Technical Issues

1. Combustion efficiency and sorbent performance

(a) Effect of parameters (coal type, sorbent type, bed depth, $\mathrm{Ca} / \mathrm{S}$ ratio, gas velocity, tempcrature, particle size, etc.)

(b) Factors for improving combustion efficiency and sulfur retention (including freeboard) 
2. Heat transfer and fluid mechanics

(a) Heat transfer to submerged coils

(b) Heat recovery from ash and spent bed material

(c) Start-up and shutdown requirements

(d) Combustion in freeboard

(e) Scale-up parameters

(f) Flow distribution and stability

3. Materials

(a) Heat exchanger tubing

(b) Air distributor plate

(c) Side walls

(d) Coal feed lines and nozzles

(e) Spend hed removal hardware

(f) Cyclones

4. Control and instrumentation
(a) Start-up, shutdown
(b) Turndown, load following
(c) Cumbustion and effluent cuntrol

5. Structural considerations
(a) Thermal expansion
(b) Vibration
(c) Tube support
(d) Bed support
(e) Furnace seals

6. Solids handling systems and component development
(a) Feed systems
(b) Ash and spent sorbent handling
(c) Cyclone performance
(d) Precipitator and bag filters
(e) Recycle of $f$ ines
(t) Utilizatlun or regcncration of spent bed material

7. Safety

8. Data base and predictive capabilities
(a) AFBC performance models
(b) Dynamic models
(c) Optimization models
(d) Predictive and design correlations (including scale-up)
(e) Data base and data retrieval

D. Environmental Control

1. Effluent control technology

2. Emission control
(a) Particulates
(b) $\mathrm{SO}_{2}$
(c) $\mathrm{NO}_{\mathrm{x}}$
(d) Other (trace elements, etc.)
(e) Comparison with pulvertzed boiler equipped with FGD

3. Solid waste disposal
(a) Toxicity and Leacháb1lily
(b) Handling problems
(c) Cost
(d) Comparison with flue-gas desulfurization (FGD) sludge 
4. Potential uses for solid waste

(a) Agricultural

(b) Roadbed, concrete, cement

(c) Other

V. AFBC PROGRAMS AND FACILITIES

A. DOE, Fossil Energy

B. EPA

C. EPRI

D. TVA

E. Other U.S.

F. International

VI. BIBLIOGRAPHY

VII. APPENDICES (as required) 
SELECTED BIBLIOGRAPHY ON ATMOSPHERIC FLUIDIZED-BED COMBUSTION

Annotated citations of 16 selected key documents on atmospheric fluidized-bed combustion and related technology are listed below in reverse chronological order. A more complete listing of relevant documentation with indexes will be provided with this report.

1. Proceedings of the Fifth Intermational Conference on Fluidized Bed Combustion (December 1977), in preparation, MITRE Corp.

More than 100 papers. Highlights include conceptual design of 570-MW(e) AFBC boilers by the three large U.S. boiler manufacturers, conceptual design and cost evaluation of elcctric power generating plants based on the AFBC boiler designs above, assessment of the impact of proposed new EPA emission standards on AFBC system energy costs, and development priorities identified during the initial operations of the Rivesville pilot plant.

2. Conversion to Coal in the Industrial and Commercial/Residential Sectors - A Study of the Barriers to Implementation in the Near Term, ORNL/TM-6139 (November 1977), NTIS (in preparation), E. C. Fox,

T. D. Anderson, H. I. Bowers, P. H. Gleick, J. R. Tallackson.

Assesses the barriers to the use of coal for process and space heat in the industrial and commercial-residential sectors. Conversion from gas or oil to coal is found to be economically attractive in large industrial sizes for some locations. Environmental concerns and governmental regulations are additional barriers to coal burning. FBC is identified as best for reducing $\mathrm{SO}_{2}$ and $\mathrm{NO}_{\mathrm{x}}$ emissions. Stoker furnaces may be preferred for reducing particulate emissions. Includes conceptual design and cost estimates for conventional and FBC coal-fired plants by United Engineers.

3. Utility Boiler Design/Cost Comparison: Fluidized Bed Combustion vs Flue Gas Desulfurization, EPA-600/7-77-126 (November 1977), in preparation.

[Neither a draft of the text nor an abstract of this recent work is yet available for review.]

4. Proceedings of the Fluidized Bed Combustion Technology Exchange Workshop, vols. I and II, CONF-770447-P-1, 2 (April 13-15, 1977), NTIS, MITRE Corp.

Includes 57 papers by FBC contractors of ERDA, EPA, and TVA. Focuses on industrial and institutional applications, utility system design studies, modeling, technology test units, technical support studies, and sorbent utilization and regeneration. 
Conclusions and recommendations from six workshop panels are presented. Workshop participants expressed concern with limitations of communications and information availability.

5. Application of Fluidized Bed Technology to Industrial Boilers, EPA-600/7-77-011 (January 1977), NTIS, PB 264,528, M. H. Farmer, E. M. Magee, and F. M. Spooner, Exxon Research and Engineering Co.

Report evaluates the ability of coal-fired FBC to meet the needs of industrial users, including cost, reliability, maintainability, design, and performance requirements. Includes estimates of likely demand for FBC in industry, the national effect on fuel demand, economic impacts, and environmental considerations. Results indicate FBC offers cost advantage with high-sulfur coals and comparable costs with low-sulfur coals. Market penetration by year 2000 is about $3 \times 10^{15}$ $\mathrm{Btu} /$ year.

6. Modeling of a Fluidized Bed Combustor with Immersed Tubes, FE-17871, 2, 3, 4, 5, 6 (December 1976), NTIS, S. C. Saxena, A. Rehmat, N. S. Geewal, and T. P. Chen, Illinois University, Chicago.

Quarterly reports. Modeling efforts aim at including coal combustion phenomena, basic mass transfer relationship, bubble mechanics, heat transfer, and configuration effects.

7. Evaluation of Phase 2 Conceptual Designs and Implementation Assessment Resulting from the Energy Conversion Alternatives Study (ECAS), NASA TM X-731515 (December 1976), NTIS, PB 270,017.

Conceptual designs are presented of seven advanced energy conversion systems for electric utility baseload applications using coal or coal-derived fuels. Estimates are presented of power plant efficiency, capital cost, environmental effects, resource requirements, and power cost. The AFB advanced steam cycle showed $35.8 \%$ efficiency, capital cost of $\$ 632 / \mathrm{kW}$, and $31.7 \mathrm{mills} / \mathrm{kWhr}$ power cost.

8. Summary Evaluation of Atmospheric Pressure Fluidized Bed Combustion Applied to Electric Utility Large Stecm Generators, vols. I and II, EPRI FP 308 (October 1976), T. E. Dowdy, W. C. Lapple, J. Kitto, T. P. Stanoch, R. H. Ball, and W. L. Sage, Alliance Research Center, Alliance, Ohio.

Includes bibliography with 645 citations. Collects and analyzes AFBC data, attempts to establish design criteria, and identifies $R \& D$ needs. Concludes that insufficient information exists to design and construct a prototype system for utility applications with a high probability of success. 
9. Studies of the Pressurized Fluidized Bed Coal Combustion Process, EPA-600/7-76-011 (September 1976), NTIS, PB 260,478, R. C. Hoke, R. R. Bertrand, M. S. Nutkis, D. D. Kinzler, L. A. Ruth, and M. W. Gregory, Exxon Research and Engineering Co.

Presents results of studies of environmental aspects of PFBC based on tests with $6-$ and $100-1 b / h r$ facilities at Exxon

$\mathrm{R} \& \mathrm{E}$. Limestone or dolomite sorbents controlled $\mathrm{SO}_{2}$ emissions to current EPA NSP standards $\left(1.2 \mathrm{lb} / 10^{6} \mathrm{Btu}\right)$, and $\mathrm{NO}_{\mathrm{x}}$ emissions were controlled to 0.2 to $0.41 \mathrm{~b} / 10^{6} \mathrm{Btu}$.

10. Benefit-Cost Evaluation of the ERDA Fossil Energy Combustion and Advanced Power Development Program, FE-2453-1 (July 1976), NTIS, L. Bestman, D. Cox, and G. Lamb, MITRE Corp.

Plant-life bus-bar electric power costs are estimated for five advanced power systems under development with ERDA/FE support and baseline competing systems. AFBC is found to have low capital cost relative to all other systems, better efficiency than baseline systems but the worst of the advanced systems, and low busbar power cost relative to all other systems.

11. Proceedings of the Workshop on Utility/Industrial Implementation of Fluidized Bed Combustion Systems, CONF-760490 (April 1976), NTIS, MITRE Corp.

Includes summary and overview; reports on (1) regulatory, institutional, and environmental requirements; (2) industrial implementation of $\mathrm{FBC}$; (3) financial and economic issues; (4) roles, relationships, and responsibilities; and (5) technical considerations; a summary of the FBC program; and the ERDA/FE FBC R\&D activities. The ERDA/FE program is endorsed, and a general optimism regarding FBC implementation is shared by 93 participants.

12. Proceedings of the Fourth International Conference on Fluidized Bed Combustion, CONF-761212 (December 1976), NTIS, MITRE Corp.

Contains 38 papers. Highlights include an overview of the British program on FBC, description of the design of the Rivesville pilot plant, assessment of technical problem areas, and an emphasis on the goal of commercialization.

13. National Fluidized-Bed Combustion Program, vols, I-V, M-75-58 (August 1974), MITRE Corp.

Prepared by MITRE for OCR; includes summary, program plan, state-of-the-art report, systems analysis and cost benefit analysis of alternative R\&D strategies, and bibliography. The bibliography contains 277 citations (88 annotated) and 25 patents. This program plan formed the basis of the ERDA/FE program, including the Rivesville pilot plant and a proposed 200-MW(e) AFBC demonstration plant. 
14. Proceedings of the Third Intermational Conference on Fluidized Bed Combustion, PB-231-977/AS (December 1973), EPA-650/2-73-053.

Contains 30 papers plus panel discussion and summary session. Includes papers on coal combustion and additive regeneration, FBC processes with fuels other than coal, gasification-desulfurization, conceptual designs and economics, and pilot plants design, construction, and operation. FBC is identified as a technology capable of burning coal cleanly.

15. Evaluation of the Fluidized Bed Combustion Process, vols. I, II, and III, PB-211494, 212 960/9, and 213 152/2 (November 1971), D. H. Ascher, D. L. Keairns, and J. R. Hamm, Westinghouse Electric Corp.
Assesses economics and pollution abatement effectiveness for FBC, including design and evaluation of a 250,000-1b/hr industrial boiler and 300- and 600-MW(e) utility boilers. PFBC with a combined cycle power plant is found to be most effec- tive in meeting projected $\mathrm{SO}_{2}$, $\mathrm{NO}_{\mathrm{X}}$, and particulate emission standards and most economical in power generation.

16. Reduction of Atmospheric Polzution, vols. 1, 2, and 3, PB-210 673, 4, and 5, NCB London (September 1971), National Coal Board, London Fluidized Combustion Control Group.

Summarizes results of British NCB studies of the reduction of $\mathrm{SO}_{2}, \mathrm{NO}_{X}$, and particulate emissions from coal combustion possible with FBC. Results from three pilot-plant combustors are presented with various coals and sorbents (limestones and dolomites). Laboratory characterizations of the coals and limestones are presented with mathematical models for correlating FBC emissions characteristics. Assessment of the effect of sorbent addition on corrosion is presented from two corrosion test combustors. Descriptions of the test units are included. 
AFBC PROJECTS AND TEST FACILITIES

The following tabulation presents a preliminary listing of AFBC projects and test facilities and cites the issues being investigated by each. A more thorough review of these projects and facilities is proposed for the execution phase. 
Performing organization:
Representative:
Project title and/or major
objective:

Sponsoring organizations and funding levels:

Period of investigation:

Location and size of facility:

Issues to be investigated and expected output:
Combustion Engineering, Inc.

W. R. Norcross

Develop, design, and construct cold model and testing bench scale and full-size 50,000-1b/hr steam plant (2.5 TPH coal) $365 \mathrm{psig}, 560^{\circ} \mathrm{F}$

DOE $\$ 5,869,300$

CE $\$ 1 ., 808,900$

$6 / 30 / 76-10 / 1 / 80$

Full scale, U.S. Naval Base, Great Lakes, I11.

Air distribution, distributor plate design, bed dynamics, immersed tube bank design with respect to bed dynamics, coal and limestone feed location, three-dimensional model
Performing organization:

Project title and/or major objective:

Sponsoring organizations . and funding levels:

Period of investigation:

Location and size of facility:

Issues to be investigated and expected output:
Georgetown University

Design, construct, test, and operate $100,000-1 b / h r$ FBC for 250-psi saturated steam

DOE $\$ 10,849,000$

Genrgetown University $\$ 3,332,000$

$6 / 30 / 76-10 / 1 / 81$

Georgetown University, Washington, D.C., 100,000-1b/hr, 250-psig saturated steam

Natural circulation, no $C B C$, recycle fines, turndown ratio $4 / 1$; boiler efficiency $\sim 83 \%$, design to meet city and EPA requirements; capacity range $15,000-150,000 \mathrm{lb} / \mathrm{hr}$ steam 


\begin{tabular}{|c|c|}
\hline Performing organization: & Battelle Columbus Labs \\
\hline Representative: & G. W. Felton \\
\hline $\begin{array}{l}\text { Project title and/or major } \\
\text { objective: }\end{array}$ & $\begin{array}{l}\text { Design, construct, and test multisolids } \\
25,000-1 \mathrm{~b} / \mathrm{hr} \text { saturated steam generator } \\
(100 \mathrm{psig})\end{array}$ \\
\hline $\begin{array}{l}\text { Sponsoring organizations } \\
\text { and funding levels: }\end{array}$ & $\begin{array}{ll}\text { DOE } & \$ 3,397,131 \\
\text { Battelle } & \$ 1,859,224\end{array}$ \\
\hline Period of investigation: & $6 / 30 / 76-10 / 1 / 82$ \\
\hline Location and size of facility: & $\begin{array}{l}\text { Columbus, Ohio; } 25,000-1 b / h r \text { sarurated } \\
\text { steam }\end{array}$ \\
\hline $\begin{array}{l}\text { Issues to be investigated } \\
\text { and expected output: }\end{array}$ & $\begin{array}{l}\text { Fluidizing vel. } \geqslant 30 \mathrm{fps} \text {, erosion of } \\
\text { heat exchanger tubes, coal feed up } \\
\text { to } 200 \mathrm{~b} / \mathrm{hr} \cdot \mathrm{ft}^{2} \text { of bed, } 1 / 8 \times 0 \text { coal }\end{array}$ \\
\hline
\end{tabular}

Performing organization:

Representative:

Project title and/or major objective:

Sponsoring organizations and funding levels:

Period of investigation:

Location and size of facility:

Issues to be investigated and expected output:
Fluidyne Engineering Corporation

H. A. Hánisurí

Design, construct, and operate AFBC on high-sulfur coal at Owatonna Tool Company for heated air $\left(900^{\circ} \mathrm{F}\right)$

DOE $\$ 2,878,385$

Fluidyne $\$ 1,537,227$

$5 / 12 / 76-9 / 1 / 81$

Owatonna, Minnesota;

18-in.-diam and $40 \times 64$ in. test facilities

Development tests on 18-in. diam using 'Lowa, 'l'ennessee coals and petroleum coke; 3 beds; long-life studies of immersed heat exchanger tubes 
Performing organization:

Representative:

Project title and/or major objective:

Sponsoring organizations and funding levels:

Period of investigation:

Location and size of facility:

Issues to be investigated and expected output:
Exxon Research and Energy Company

L. P. Golan

Evaluation of application of AFBC to indirect process heaters

DOE $\$ 3,274,757$

Exxon $\$ 733,618$

$6 / 30 / 76-3 / 1 / 80$

Two-dimensional flow visualization unit ( $7.5 \times 12 \times 1.5 \mathrm{ft}$ ); pipe still unit, fluidized-bed heat flux unit, 10-15 M Btu/hr coal-fired FBC

Effects of larger tube sizes, 2-, 4-, and 6-in.-diam; 2-D, 3-D, 4-D tube spacing, bed particle size, fluidizing vel., grid design, bed pressure drop, hydrocarbon coking, heat flux rates, 15,000-100,000 Btu/ $\mathrm{hr} \cdot \mathrm{ft}^{2}$. Fluidized-bed heat flux: bed temperature, $1000-1600^{\circ} \mathrm{F}$; fluid vel. 20 fps
Performing organization:

Representatives:

Project title and/or major objective:

Sponsoring organization and funding level:

Period of investigation:

Issues to be investigated and expected output:
MIT Energy Lab

S. E. Tung and A. F. Sarofim

Develop model for FBC process; provide future R\&D planning; establish data base on $\mathrm{FBC}$

DOE $\$ 945,000$

$5 / 76-1 / 78$

Models being developed, slow bubble fluidization model; one-phase model; heat transfer model (modified Vreedenberg); solids mixing; devolatization, coal combustion (modified Davidson), desulfurization (Borgwardt mode1), FBC transient behavior, kinetics; attritionelutriation; data base - 9 systems evaluated; 2 selected, abstraction of data from papers and reports 
Performing organization:

Representative:

Project title and/or major objective:

Sponsoring organization and funding level:

Period of investigation:

Location and size of facility:

Issues to be investigated and expected output:
Department of Agriculture, Agricultural Research Service

0. L. Bennett

Evaluate FBC waste in strip mine reclamation, improvement of marginal lands, maintain proper $\mathrm{pH}$, as source of $\mathrm{Ca}$ in crops

DOE $\$ 1,767,000$

$7 / 1 / 76-7 / 1 / 81$

Future new lab, greenhouse Field studies: Morgantown, W. Va., Beltsville, Md., University Park, Pa., Blacksburg, Va.

Chemical and physical characteristics of FBC waste; rates of elemental release; elemental availability to plants; effectiveness of $F B C$ material as liming material and source of pl.ant nutrients; effects on plant growth; effectiveness of $F B C$ material as soil amendment on m1ne spoils
Performing organization:

Project title and/or major objective:

Sponsoring organization and funding level:

Period of investigation:

Issues to be investigated and expected output:
TVA

Agronomic evaluation of $\mathrm{FBC}$ waste material

DOE $\$ 29,000$

$4 / 1 / 76-1 / 31 / 78$

Use of waste material as liming material and source of sulfur and nutrients on growth of corn and peanuts 


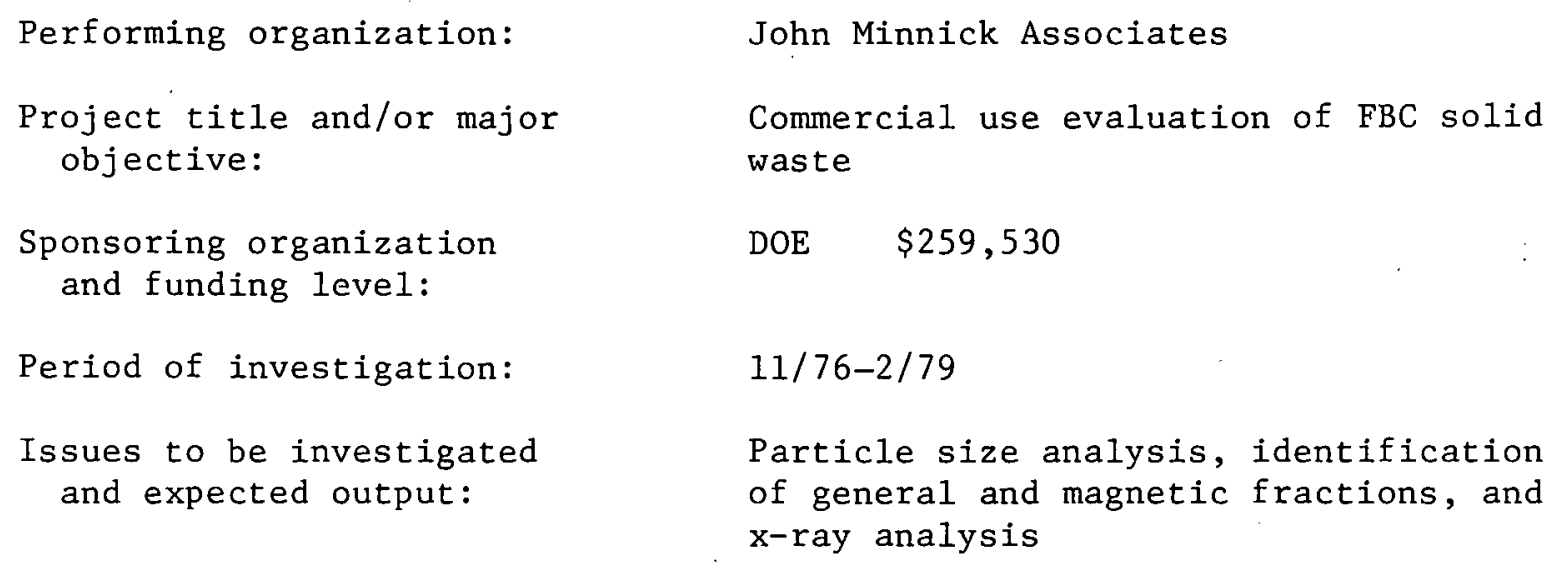

John Minnick Associates

Commercial use evaluation of FBC solid waste

DOE $\$ 259,530$

$11 / 76-2 / 79$

Particle size analysis, identification of general and magnetic fractions, and $\mathrm{x}$-ray analysis

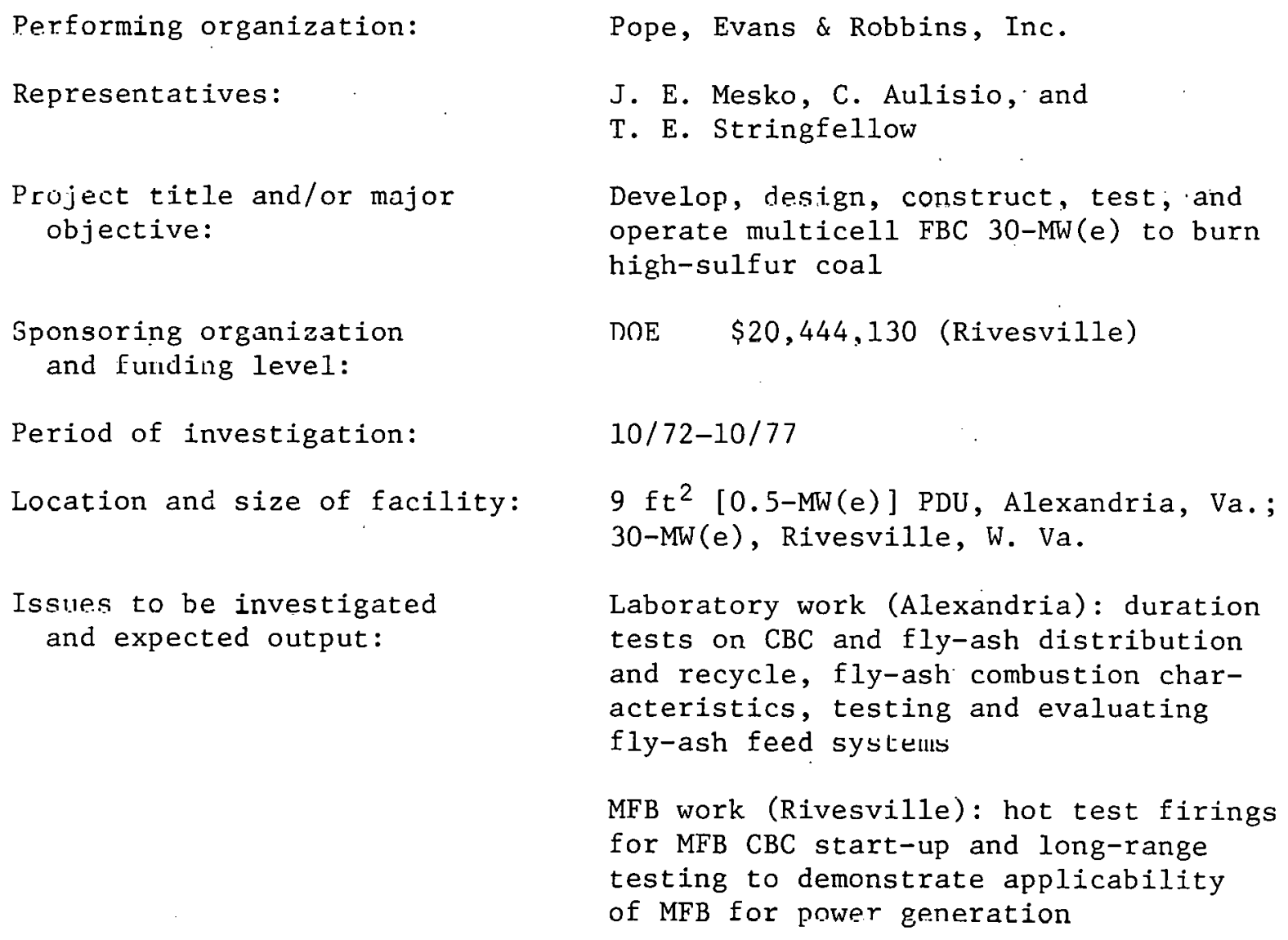

Performing organization:

Representatives:

Project title and/or major objective:

Sponsoring organization and funding level:

Period of investigation:

Location and size of facility:

Issues to be investigated and expected output:

Pope, Evans \& Robbins, Inc.

J. E. Mesko, C. Aulisio, and

T. E. Stringfellow

Develop, design, construct, test, and operate multicell FBC 30-MW(e) to burn high-sulfur coal

DOE $\$ 20,444,130$ (Rivesville)

$10 / 72-10 / 77$

$9 \mathrm{ft}^{2}$ [0.5-MW(e)] PDU, Alexandria, Va.; 30-MW(e), Rivesville, W. Va.

Laboratory work (Alexandria): duration tests on $C B C$ and fly-ash distribution and recycle, fly-ash combustion characteristics, testing and evaluating fly-ash feed systemls

MFB work (Rivesville): hot test firings for MFB CBC start-up and long-range testing to demonstrate applicability of MFB for power generation 
Performing organization:

Representatives:

Project title and/or major objective:

Sponsoring organization and funding level:

Period of investigation:

Location and size of facility:

Issues to be investigated and expected nutput:
ORNL

R. S. Hol comb and G. Samuels

Develop technology to heat air by FBC for use in cogeneration with closedcycle gas turbines and process heat utilization

DOE $\$ 6,743,000$

$5 / 1 / 74$ and continuing

Oak Ridge, Tenn. TTU $6 \times 6$ ft;

$4 \times 4$ ft cold flow model

Development of performance specification for ouitability to clused=cycle hot-air gas turbine generator system [5-50 Mw(e)], heat transfer studies $1 / 16-1 / 8$ in. particle size, $0.8-2.5$ fps; sulfur capture $1550-1650^{\circ} \mathrm{F}, 0.8-2.5$ fps; coal feeder systems; ash handling systems; bed solids recycle
Performing organization:

Representatives:

Project title and/or major objective:

Sponsoring organization and funding level:

Period of Investigation:

Location and size of facility:

Issues to be investigated and expected output:
MERC

J. S. Wilson, J. W. Byam, and J. S. Mei

Evaluate combustion charactertatiss, effluent emissions, sulfur sorbents on bench scale and AFBC/CTIU

DOE $>\$ 18,900,000$

$7 / 75$ and continuing

Morgantown, West Virginia. 18-in. diam; $6 \times 6 \mathrm{ft} ; 6 \times 6 \mathrm{ft}$ cold model.

18-in. diam - study effects of additives to control $\mathrm{SO}_{2}$ emissions; define operating parameters for combustion efficiency, limestone consumption, emissions; operation with various coals and refuses. $6 \times 6 \mathrm{ft}$ - materials handling and feed system; boiler optimization, combustion studies, hardware development; emission control. 6 × $6 \mathrm{ft}$ cold model - component testing for CTIU and PER Rivesville $30 \mathrm{MW}(\mathrm{e})$ 


$\begin{array}{ll}\begin{array}{l}\text { Performing organization: } \\ \text { Representative: }\end{array} & \begin{array}{l}\text { Spectron Development Laboratory, Inc. } \\ \text { William D. Bachalo }\end{array} \\ \begin{array}{l}\text { Project title and/or major } \\ \text { objective: }\end{array} & \begin{array}{l}\text { Assess capability of advanced diagnos- } \\ \text { tics for particle measurement in FBC }\end{array} \\ \begin{array}{l}\text { Sponsoring organization } \\ \text { and funding level: }\end{array} & \text { Doe } \$ 17,219 \\ \begin{array}{l}\text { Period of investigation: } \\ \begin{array}{l}\text { Issues to be investigated } \\ \text { and expected output: }\end{array}\end{array} & \begin{array}{l}5 / 76-2 / 77 \\ \text { Work completed on ANL FBC for particle } \\ \text { measurement }- \text { in situ measurement, } \\ \text { simultaneous size, and velocity measure- } \\ \text { ment, electronic processing }\end{array}\end{array}$

Performing organization:

Representative:

Project title and/or major objective:

Sponsoring organization and Furding level:

Period of investigation:

Location and size of facility:

Issues to be investigated and expected output:
Grand Forks ERC

G. M. Goblirsch

Develop alternative methods of control of $\mathrm{SO}_{\mathrm{x}}$ from low-S lignite, reduce cost, improve reliability, removal efficiencies

DOE $\$ 500,000$

$10 / 1 / 76$ and continuing

Grand Forks, N.D. 6-in. diameter

With high-alkaline ash from lignite, determine standard conditions for alkali availability, $\mathrm{SO}_{\mathrm{x}}$ removal, scaling rates, examine wider range of $\mathrm{fly}$ ashes; determine material balance on major and trace elements, recycle of fines, and injection of catalysts in flue gas for $\mathrm{SO}_{2}$ removal 


\section{Performing organization: \\ Representative: \\ Project title and/or major objective:}

Sponsoring organizations and funding lcvels:

Period of investigation:

Location and size of facility:

Issues to be investigated and expected output:
University of Illinois

S. C. Saxena

Develop mathematical model of FBC including coal combustion and basic mass transport, bubble mechanics, high temperature, and configuration effects; cold-test model to be constructed

DOE $\$ 89,016$

University of Illinots $\$ 28,670$

$5 / 9 / 75-5 / 8 / 77$

University of Tllinois, Chiragn

Mechanistic model already developed for noncatalytic gas-solid reactions in fluidized beds will be expanded to include effect of air fluidization velocity, particle size, nature of solid particles, tube diameter, tube arrangement, average tube-to-bed high-temperature coefficient, particle size distribution in bed will be determined

\section{Performing organization: \\ Representatives: \\ Project title and/or major objective:}

Sponsoring organizations and funding levels:

Period of investigation:

Location and size of facility:

Issues to be investigated and expected output:
Lehigh University

E. K. Levy and J. C. Chen

Determine feasibility of operating centrifugal FRC in rontinunus modo

DOE $\$ 138,997$

Lehigh University \$24,972

$9 / 76-9 / 78$

Lehigh University

Determine requirements for minimum fluidization, bed pressure drop, freeboard pressure drop, effeces of bed addition and removal, bed start-up, distributor design, fluid mechanics of confined vortex flows 
Performing organization:

Representatives:

Project title and/or major objective:

Sponsoring organizations and funding levels:

Period of investigation:

Location and size of facility:

Issues to be investigated and expected output:
New York University

V. Zakkay and G. Miller

Investigate interrelationships of temperature distribution, fluid flow, and heat exchanger in fossil-fuel-fired FBC

DOE $\$ 574,000$

New York University $\$ 17,000$

$2 / 1 / 76-1 / 31 / 78$

New York University, 1-ft diameter, future - 4-ft diameter

Detailed work on 1-ft-diam bed produced velocity distribution data, pressure fluctuations, information on initial heating cycles; heat transfer film coefficients as function of bed tube geometry and air velocity will be optimized, correlation developed for 4-ft-diam bed will be completed and different tube configurations tested
Performing organization:

Representative:

Project title and/or major objective:

Sponsoring nrganization and funding level:

Location and size of facility:

Issues to be investigated and expected output:
Babcock \& Wilcox

S. S. Strom

Design, develop, construct, test, and operate $6 \times 6 \mathrm{ft}$ AFBC for bridge between bench scale and large plant demonstrations

EPRI $\$ 2,000,000$

$6 \times 6 \mathrm{ft}$

Engineering and economic evaluation, $\mathrm{SO}_{2}$ and particulate control, solid waste management, improved combustion efficiency, effect of oxidizing-reducing environment on metals, effect of parameters on heat transfer, prototype and commercial development, design conditions $-8 \mathrm{fps}, 1880 \mathrm{lb}$ coal per $\mathrm{hr}$, $\sim 7 \mathrm{MW}(\mathrm{t})$, saturated steam $=10,000 \mathrm{Ib} / \mathrm{hr}$ at 150 psig, $\sim 1600^{\circ} \mathrm{F}$ bed temperature, superheat steam $=2000 \mathrm{lb} / \mathrm{hr}$ at $1000^{\circ} \mathrm{F}$ 


\begin{tabular}{|c|c|}
\hline Performing organization: & MERC \\
\hline Representatives: & J. S. Wilson, J. W. Byam, and J. S. Mei \\
\hline $\begin{array}{l}\text { Project title and/or major } \\
\text { objective: }\end{array}$ & $\begin{array}{l}\text { To examine combustibility of anthracite } \\
\text { refuse waste, oil shale, lignite, and } \\
\text { bituminous refuse as means for fuel and } \\
\text { environmental value }\end{array}$ \\
\hline Sponsoring organization: & DOE \\
\hline Yeriod of investigation: & 76 and continuing \\
\hline Location and size of facility: & 18-in. diam, Morgantown, W. Va. \\
\hline $\begin{array}{l}\text { Issues to be investigated } \\
\text { and expected output: }\end{array}$ & $\begin{array}{l}\text { Determining combustion characteristics } \\
\text { of these waste materials and poor } \\
\text { quality fuels; provide technical back- } \\
\text { ground for developing an anthracite culm } \\
\text { utilization-demonstration plant }\end{array}$ \\
\hline
\end{tabular}

J. S. Wilson, J. W. Byam, and J. S. Mei

To examine combustibility of anthracite refuse waste, oil shale, lignite, and bituminous refuse as means for fuel and environmental value

DOE

76 and continuing

Determining combustion characteristics of these waste materials and poor quality fuels; provide technical backutilization-demonstration plant

\author{
Performing organization: \\ Project title and/or major \\ objective: \\ Sponsoring organization \\ and funding level: \\ Issues to be invest1gated \\ and expected output:
}

U.S. Dept. of Transportation, Federal H1ghway Administration

To determine applicability of FBC waste material as soil treatment and stabilizer for highway subbase

DOE $\$ 43,000$

To test and determine if $\mathrm{FBC}$ waste (mainly $\mathrm{CaSO}_{4}$ and active lime) can he used instead of portland cement in various geugraphic areas as subbase for highways 


\section{Performing organization: \\ Project title and/or major objective:}

Sponsoring organization and funding level:

Period of investigation:

Location and size of facility:

Issues to be investigated and expected output:
Argonne National Laboratory

Analysis of the process control requirements of fluidized-bed demonstration plants; development of needed instrumentation

DOE $\$ 1,500,000$

$6 / 76-9 / 77$

Argonne, I1I.

Argonne is developing equipment for measuring solid-liquid mass flow rates; symposium on process control instrumentation was held in July 1977
Performing organization:

Representatives:

Project title and/or major objective:

Spunsoring organizations:

Issues to be investigated and expected output:
Argonne National Laboratory

A. A. Jonke and C. J. Vogel

Examination of synthetic sorbent performance; regeneration process model; sorbent life studies with dolomite and limestone; investigation of use of additives to increase sorbent reactivity; characterization of the $\mathrm{SO}_{2}$ sorption properties of limestone and dolomite

EPA and DOE

Argonne is conducting theoretical and experimental studies using a 6 -in. pressurized combustor $\left(117 \mathrm{psi}, 900^{\circ} \mathrm{F}\right)$ and a 4.25-in. pressurized regenerator (22 psi, $2012^{\circ} \mathrm{F}$ ); synthetic sorbents to be examined include $\mathrm{CaO}, \mathrm{SrO}, \mathrm{BaO}, \mathrm{Na}_{2} \mathrm{O}$, and $\mathrm{K}_{2} \mathrm{O}$ on alumina; process flowsheets for FBC power plants with sorbent: regeneration will be devised 


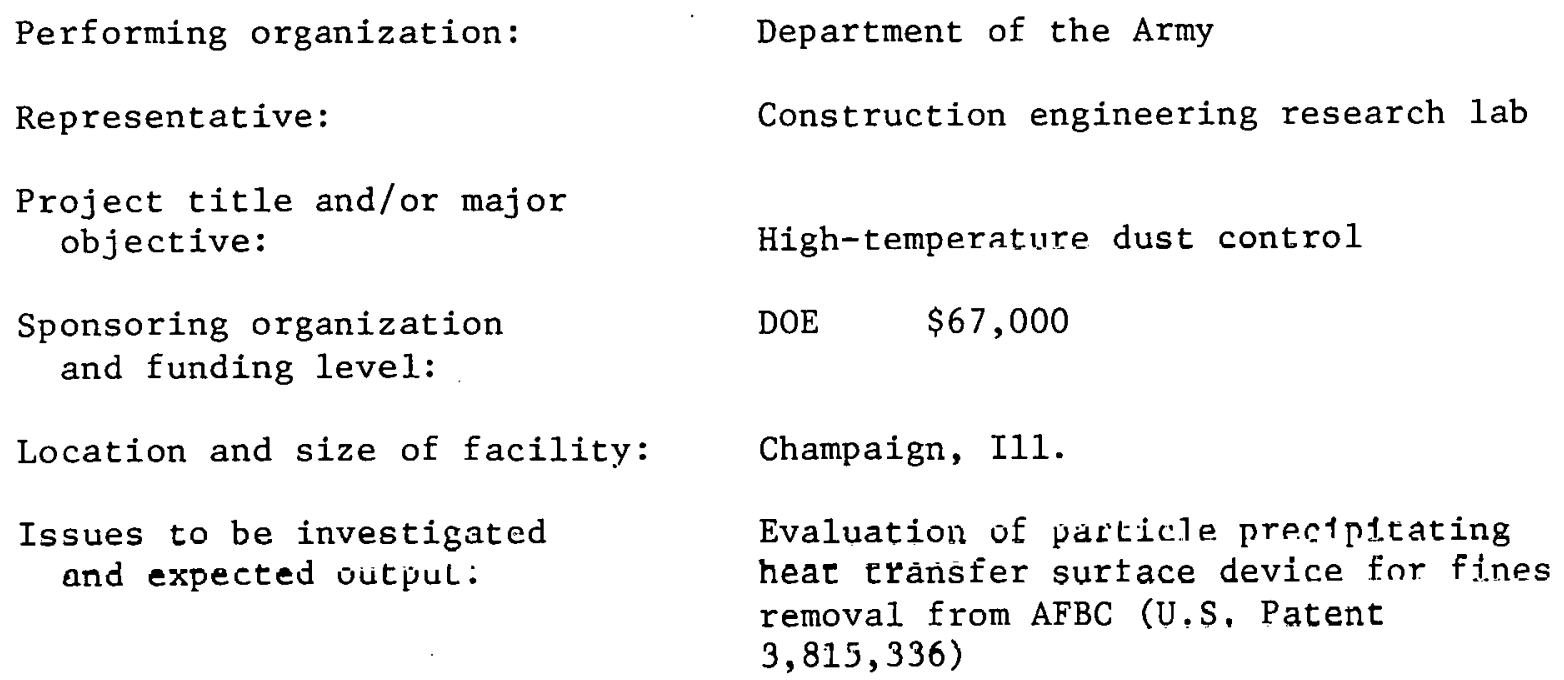

Performing organizations:

Project title and/or major objective:

Sponsoring organizations and funding levels:

Issues to be investigated and expected output:
Combustion Engineering, Babcock \& Wilcox, Foster-Wheeler

Preliminary design of a 150-250 MW(e) AFBC demonstration plant; development of design bases and parameters required for preliminary boiler design based on existing technology; evaluation of conceptual designs and costs for a 600-1000 MW(e) commercial plant; assessment of the state of the art, definition of problem areas, and determination of environmental impacts for the proposed plant

DOE and TVA $\$ 4,000,000$ (Phase I)

Phase I involves preliminary design and cost estimates; this degign is based on. high-sulfur eastern coal feedstock; each contractor is doing a preliminary design of a demonstration plant; based on these designs, a decision will be made on construction of the platit 


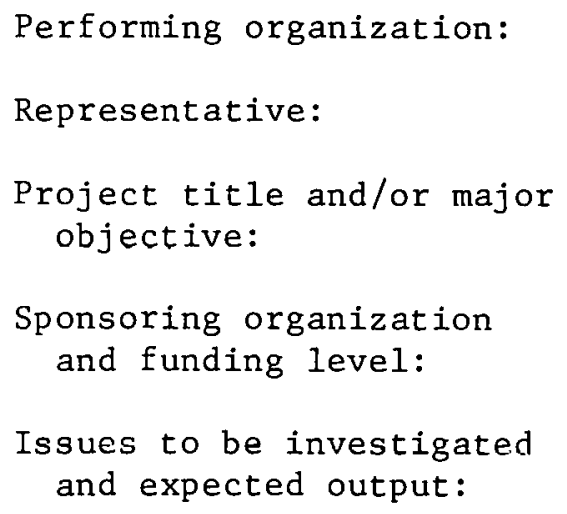
Babcock \& Wilcox
Howard B. Lange
Effect of particle size on limestone utilization for $\mathrm{SO}_{2}$ capture
EPRI $\$ 378,000$
Study involves experimental evaluation and correlation of the results of par- ticle size in a $9-\mathrm{ft}^{2}$ hot bed with a once-through sorbent system; three types of limestone and hydrated lime were used with Pittsburgh No. 8 coal ( $23 \% \mathrm{~S})$; while decreased particle size increased utilization of calcium in the bed, increased elutriation of the sorbent caused no marked overall effect on calcium utilization

Performing organization:

Project title and/or major objective:

\section{Sponsoring organizations:}

Issues to be investigated and expected output:

\section{Battelle Columbus Laboratory}

Evaluation of sampling and analysis techniques for the comprehensive analysis of emissions from FBC units

EPA and EMI

Battelle's 6-in.-ID AFBC unit with coal and limestone bed was used; for the analysis, operating conditions were: 9-17 lb/hr coal, 4.3-18 lb/hr limestone, 87-151 lb/hr air rate, 48 in. bed height, $1525-1655^{\circ} \mathrm{F}$ bed temperature, 6-9.4 fps घH velocity, 2.9-7.7 Ca/S ratio; samples of gases, particulates, and solid wastes were analyzed 
Performing organizations:

Project title and/or major objective:

Sponsoring organization and funding level:

Issues to be investigated and expected output:
Battelle Columbus and Stellite Division of Cabot Corporation

Determination of the effect of alloy variables on material resistance to corrosion and erosion; establishment of alloy design criteria and evaluation of system designs using them

EPRI $\$ 200,000$

Study will examine the corrosion and erosion characteristics of various alloys
Performing organization:

Representatives:

Project title and/or major objective:

Sponsoring organizations and funding levels:

Issues to be investigated and expected output:
Battelle Columbus Laboratory

K. S. Murthy and H. Nack

Environmental assessment; recommended efinission standards; manuals of best available control tcchnology; planting of R\&D pringram

EPA and EMI $\$ 200,000$

Battelle will perform environmental support studies on alternative sorbents, regeneration, $\mathrm{NO}_{x}$ formation and control, trace elements, solid and liquid wastes, and parliculale concrol; in addition, existing environmental, engineering, and cost data will be revlewed for identification of major pollutants and projection of attainable emission levels; environmental data gaps will be identified and programs designed to fill these gaps, including a source sampling and monitoring program 
Performing organization:

Representative:

Project title and/or major objective:

Sponsoring organizations and funding levels:

Issues to be investigated and expected output:
Battelle Columbus Laboratory

A. M. Hall

Heat exchanger materials, corrosion and erosion data, data correlation with alloy properties

DOE and MERC $\$ 769,000$

A 3-ft-diam bed will be used at Columbus, Ohio, to determine the erosion and corrosion of $9 \mathrm{Cr}-1,5 \mathrm{Mo}, 304$ stainless, $\mathrm{HK}-40$ (310), Inconel 671, and $\mathrm{X}-40$ alloys as $3 / 16-i n$. heat exchanger tubes located in and above the bed; a 2000-hr run with bed operating conditions of 7.6 fps fluidizing velocity, excess air $15-20 \%$, and $1575^{\circ} \mathrm{F}$ temperature, will be used for obtaining data with an Illinois No. 6 coal and limestone bed

\section{Performing organization:}

Project title and/or major objective:

Sponsoring organization and funding level:

Issues to be investigated and expected output:
Bradford University

Effect of coal and limestone fines on combustion and sorbent efficiency

EPRI $\$ Y U, 000$

Cold modeling will be performed to determine the fluid mechanics of fines 
Performing organizations:

Project title and/or major objective:

Sponsoring organizations and funding level:

Period of investigation:

Issues to be investigated and experted nutput:
Burns \& Roe; Stone \& Webster

Design and project costs for commercial size [200-800 MW(e)] AFBC electric power generating plant

DOE

$\$ 1,321,000$ to Burns \& Roe

$\$ 1,354,000$ to Stone \& Webster

$1 / 77-1 / 78$

- Plant design for 600-MW(e) AFBC using noncompliance westein cual - Butus \& Roe

- Plant dcoign for 570-PW(e) AFDC usling high-S eastern coal - Stone \& Webster

- Provide conceptual design for AFBC demonstration plant
Performing organization:

Project title and/or major objective:

\section{Sponsoring organization} and funding level:

Period of investigation:

Issues to be investigated and expected output:
Foster Miller Associates

Determination of feeder requirements for coal conversion plant and development of systems

DOE $\$ 1,279,000$

$9 / 76-1 / 78$

Four feeder syctemo will be carried through laboratory-scale design and testing. Best candidate will be installed in pilot unit for further testing 
Performing organization:

Project title and/or major objective:

Sponsoring organization and funding level:

Period of investigation:

Size of facility:

Issues to be investigated and expected output:
General Electric

Two-phase flow and heat transfer in fluidized beds

EPRI $\$ 553,000$

$8 / 75-9 / 78$

Cold model $1-\mathrm{ft}^{2}$ and $4-\mathrm{ft}^{2}$ beds

Design data for full-scale units

1) Effects of scaling and air distribution configuration

2) Effects of pressure scaling

3) Heat transfer from bed to immersed tubes
Performing organization:

Project title and/or major objective:

Sponsoring organization and funding level:

Period of investigation:

Issues to be investigated and expected output:
MERC

Fouling and slagging of fireside surfaces in coal-fired hoilers

DOE $\$ 567,000$

$6 / 75-12 / 78$

Determine effects and causes of fouling and slagging using low-rank western coals in pulverized coal boilers; effects of additives 
Performing organization:

Project title and/or major objective:

Sponsoring organization and funding level:

Period of investigation:

Size of facility:

Issues to be investigated and expecled unlput:
Oregon State University

Investigation of point-to-point heat transfer in fluidized bed with immersed tubes

EPRI $\$ 381,000$

$6 / 75-6 / 78$

$10-\mathrm{ft}^{2}$ bed cold model

Develop model and construct cold-model her tor bundle design with respect to operating parameters (bubble formation, solids mixing, calculation) control and design optimization of heat exchange system for $B \& W$ FBC facility 
ORNL/TM-6208

INTERNAL DISTRIBUTION
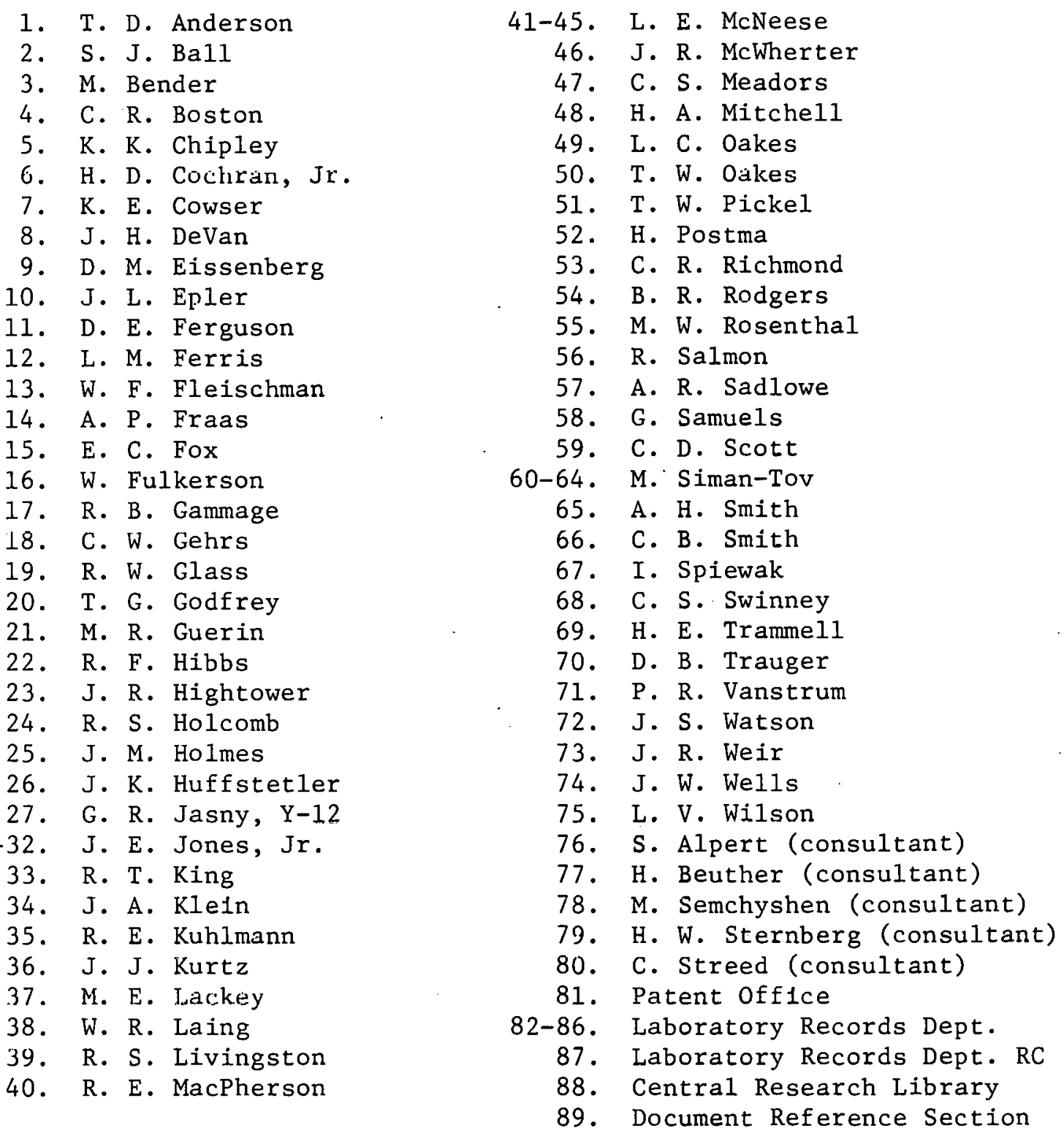

EXTERNAL DISTRIBUTION

DOE-FE, Washington, DC

90. E. K. Bastrass

91. J. A. Belding

92. W. M. Crim

93. S. J. Dapkunas
94. C. W. DiBella

95. J. Eustis

96. T. R. Facey

97. H. Frankel 
98. S. I. Freedman

99. L. M. Joseph

100. C. A. Kinney

101. C. Knudsen

102. E. Lister

103. W. A. McCurdy
104. J. W. Neal

105. M. Neuworth

106. W. T. Saunders

107. E. C. Trexler

108. J. G. Vlahakis

109. H. L. Weisenfeld

110. The Director, DOE Morgantown Energy Research Center, P.0. Box 800, Morgantown, WV 26506

111. John Wilson, DOE Morgantown Energy Research Center, P.0. Box 800, Morgantown, WV 26506

112. Research and Technical Support Division, DOE-ORO

113. H. L. Falkenberry, Tennessee Valley Authority, Chattanooga, IN 37401

114. C. Gottschalk, Tennessee Valley Authority, Chattanooga, IN 37401

115. M. J. Mayfield, Tennessee Valley Authority, Chattanooga, TN 37401

116. H. W. Withers, Tennessee Valley Authority, Chattanooga, TN 37401

117. Floyd L. Culler, Office of the President, Electric Power Research Institute, Post Office Box 10412, 3412 Hillview Avenue, Palo Alto, CA 94303

118. Kenneth P. Lue Phang, Developmental Engineering Staff, Tennessee Valley Authority, 220 Liberty Building, Knoxville, TN 37902

119. Duane G. Nichols, Energy and Environmental Research Division, Research Triangle Institute, Post office Box 12194, Research Irlangle Park, NC 27709

120. Fred N. Peebles, Dean of Engineering, University of Tennessee, Knoxville, TN 37916

121. E. H. Reich1, President, Conoco Coal Development Co., High Ridge Park, Stamford, CT 06904

122. C. B. Sedman, U.S. Environmental Protection Agency, Research Triangle Park, NC 27711

123. A. G. Sharkey, DOE Pittsburgh Energy Research Center, 4800 Forbes Ave., P1ttsburgh, PA 15213

124. Donald C. Thomas, Tennessee Valley Authority, 1360 Commerce Union Bank, Chattanooga, TN 37401

125. Theresa Wiley, Institute Librarian, University of Kentucky, Institute for Mining and Materials Research, 213 Bradley Hall, Lexington, KY 40506

126-152. Technical Information Center, DOE-ORO 